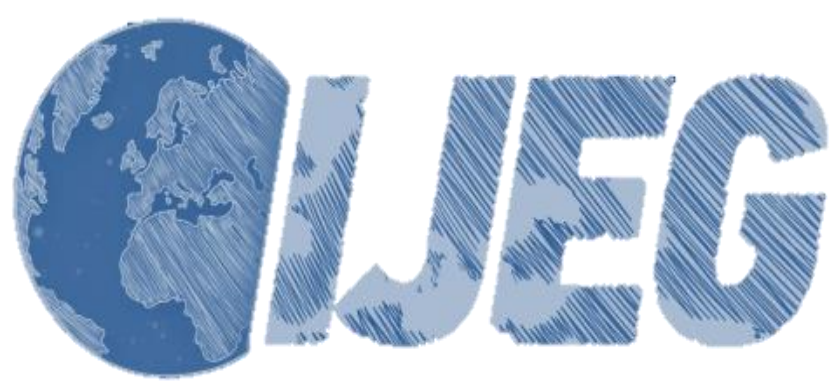

International Journal of Engineering and Geosciences (IJEG),

Vol; 3; , Issue; 1, pp. 020-035, February, 2018, ISSN 2548-0960, Turkey, DOI: 10.26833/ijeg.357161

\title{
RADIOMETRIC IMPACT ASSESSMENT AROUND TWO QUARRY SITES, BENIN-OWO EXPRESS WAY, SOUTHWESTERN NIGERIA
}

\author{
Ademila, O. \\ Adekunle Ajasin University, Science Faculty, Department of Earth Sciences, Akungba Akoko, Nigeria \\ (omowumi.ademila@aaua.edu.ng)
}

ORCID $0000-0001-5177-1110$

*Corresponding Author, Received: 23/11/2017, Accepted: 30/12/2017

\begin{abstract}
Total reliance on quarry products as construction materials has prompted commercial quarry activities globally. However, potential risks introduced by radiation exposure to quarries in two different locations in Ondo State, Nigeria were assessed to evaluate the background radiation and distribution of naturally occurring radionuclides associated with these areas. A ground radiometric mapping of eleven traverses across the two quarry sites was carried out using Gamma ray spectrometer. Naturally occurring radionuclides ${ }^{238} \mathrm{U},{ }^{232} \mathrm{Th}$ and ${ }^{40} \mathrm{~K}$ in natural quarried materials of coarse rock aggregates and soil samples collected at a maximum depth of $2 \mathrm{~m}$ and up to $500 \mathrm{~m}$ away from the quarry sites were measured using gamma spectrometry method. Spectrometric data were processed and presented in form of radiometric maps showing the distribution of radiation level in each location. Results show that activity concentrations varied from one location to another. The radiation level in the recently quarried coarse rock aggregates (QF1 and QF2) (372 cps and 382 cps) are higher than the previously quarried coarse rock aggregates (QP1 and QP2) (365 cps and $377 \mathrm{cps}$ ) of the quarry sites. Activity concentrations in soils are in the order ${ }^{232} \mathrm{Th}<{ }^{238} \mathrm{U}<{ }^{40} \mathrm{~K}$. The mean radioactivity concentration values of ${ }^{232} \mathrm{Th},{ }^{238} \mathrm{U}$ and ${ }^{40} \mathrm{~K}$ are $0.0027 \pm 0.0003 \mathrm{~Bq} / \mathrm{kg}, 0.028 \pm 0.0012 \mathrm{~Bq} / \mathrm{kg}, 47.45 \pm 0.0313 \mathrm{~Bq} / \mathrm{kg}$ and $0.0036 \pm 0.00036 \mathrm{~Bq} / \mathrm{kg}$, $0.026 \pm 0.0012 \mathrm{~Bq} / \mathrm{kg}$ and $69.42 \pm 0.0313 \mathrm{~Bq} / \mathrm{kg}$ respectively for soils within the quarries. At $500 \mathrm{~m}$ away from the quarry sites, mean values are $0.0008 \pm 0.75 \mathrm{~Bq} / \mathrm{kg}, 0.020 \pm 0.0012 \mathrm{~Bq} / \mathrm{kg}, 41.54 \pm 0.0313 \mathrm{~Bq} / \mathrm{kg}$ and $0.0049 \pm 0.0004 \mathrm{~Bq} / \mathrm{kg}$, $0.052 \pm 0.0012 \mathrm{~Bq} / \mathrm{kg}$ and $200.32 \pm 0.0313 \mathrm{~Bq} / \mathrm{kg}$ respectively. The radiological hazard indices calculated were used to access the health implication of exposure to rock aggregates and soil of the study areas. The values obtained when compared with their corresponding world permissible values were found to be below the internationally recommended values. Therefore, the level of radiation and interaction with the rock aggregates and soils do not expose the workers and people within and around the quarries to health problem. Hence, the quarry products can be used as building material for housing and road constructions.
\end{abstract}

Keywords: Quarries, Radiometric mapping, Radionuclides, Hazard indices, Rock aggregates 


\section{INTRODUCTION}

Unwholesome activities of man have led to environmental degradation and health hazard of different kinds. Human exposure to background radiation originated from natural and man-made sources. Naturally occurring radionuclides contribute significantly to the exposure of human for radiation. The commonest of these radionuclides are the radioactive isotope of potassium ${ }^{40} \mathrm{~K}$ and the radionuclides originated from the decay of ${ }^{238} \mathrm{U}$ and ${ }^{232} \mathrm{Th}$ series, both widely distributed in soil and rocks of the earth's crust. Natural environmental radioactivity concentrations and the associated external exposure due to gamma radiation depend mainly on geological and geographical conditions and appear at different levels in soils of each region in the world (UNSCEAR, 2000). Monitoring the terrestrial background radiation is very important due to the activity concentration of natural radionuclides in soil. When rocks are disintegrated through natural process, radionuclides are carried to soil by rain and flows (Taskin et al., 2009).

Quarrying operations have hazard effects on workers. Higher radiation levels are associated with igneous rocks, such as granite, and lower radiation levels with sedimentary rocks. Working activities carried out in quarries is a source of potential exposure because of natural radioactivity high levels arising from a large amount of primary radionuclides in the ${ }^{238} \mathrm{U}$ and ${ }^{232} \mathrm{Th}$ series and ${ }^{40} \mathrm{~K}$. A worksafe study has estimated that 2200 people die each year from various illnesses such as silicosis, pneumoconiosis and cancers caused by or associated with exposures to hazardous substances in the workplace. This is 4 to 5 times higher than the number of deaths from traumatic injury and so control of hazardous substances must be given highest priority (David, 1998). Quarrying activity involves mostly blasting and crushing of granite rocks and generates a lot of dust when processing. Dusts are one of, if not the major hazard to health from substances in quarries. Dust is generated at all stages of the production process and the smallest, indeed invisible particles are the most hazardous due to their ability to reach the lower part of the lung (the alveole). The most widely recognized hazardous component of the dust is crystalline silica which due to excessive exposure can cause severe respiratory problems or even silicosis and cancer. None of the commonly quarried rocks can be guaranteed silica free. Rocks classified as limestone have been shown to contain up to $40 \%$ crystalline silica and granite $55 \%$ crystalline silica. Quartzites and natural sands are normally in the range $80-100 \%$ crystalline silica. Exposure to silica dust during stone cutting in quarries carries the risk of development of silicosis, progressive massive fibrosis, asthma, chronic obstructive pulmonary disease, and airways obstruction in exposed workers (James, 2013). These airborne dusts $(1 \mu \mathrm{m}$ to $100 \mu \mathrm{m}$ in diameter) are mainly in the form of particulates, which produced through the mechanical processes such as breaking, grinding and pulverizing, and the primary route of exposure is inhalation (Tim et al., 2004).

Studying the levels of radionuclide distribution in the environment provides essential radiological information.
Many sicknesses and diseases manifest after repeated and long exposure to radiation have been attributed to other sources and the nature and severity of the symptoms depend on the absorbed dose and the dose rate of radionuclides. Unfortunately, the sickness may take years to become evident, and indeed, when manifest it may already be too late. Hence, the knowledge of the natural radioactivity concentration of our environment is essential in the assessment of the degree and extent of radioactive contamination or pollution in the environment. In the quarrying industry, some of the most significant exposures to hazardous substances might be associated with the interaction of ionizing radiation with the human body, dust generated in the process or with fumes from vehicle exhausts and use of explosives. All these lead to various biological effects which may later show up as clinical symptoms. Data regarding levels of natural radioactivities in soils, rocks and the corresponding radiation doses to the people are lacking for most parts of Nigeria, as soil and rock radioactivity is also affected by man-made activities. The present study is necessitated on the need for protection from environmental pollution arising from environmental radioactivity, migration and evolution of radionuclides. So, this study was undertaken to evaluate the natural radionuclides activities of ${ }^{238} \mathrm{U},{ }^{232} \mathrm{Th}$ and ${ }^{40} \mathrm{~K}$ in order to assess the background radiation and distribution of these radionuclides in the soils and rocks in the vicinity of two quarries in Ondo State and to determine the radiological impact of these nuclides on health of the workers and populace within and around these quarries with a view of appraising the environmental quality of the study areas. The radiological information would in-turn be used to determine whether a potential threat to human health in the environment exists that would warrant consideration of a remedial action.

\section{LOCATION AND GEOLOGIC SETTING OF THE STUDY AREA}

The study areas are Ebenezer Mining and Ceramics Company (Location 1) is situated in ancient city of Akure, Akure South local government area of Ondo State, Southwestern Nigeria. It lies within latitudes $7^{\circ} 10^{\prime} \mathrm{N}$ and $7^{\circ} 19^{\prime} \mathrm{N}$ and longitudes $5^{\circ} 07^{\prime} \mathrm{E}$ and $5^{\circ} 14^{\prime} \mathrm{E}$ (Fig. 1). It covers an area extent of about $1.5 \mathrm{~km}^{2}$ and it's easily accessible to other major and urban centres in the state. It is bounded by Owo to the east, Ado -Ekiti to the north and Ondo to the south, all within $50 \mathrm{~km}$ radius. Within $100 \mathrm{~km}$ radius, it is bounded by Ikare, Ikole Ekiti, Ijero Ekiti to the north and Okitipupa to the south.

Ballister Mining Company (Location 2) is found on kilometer 20, Owo-Benin express way in Ose local government area of Ondo State, Nigeria. It is situated on latitudes $7^{\circ} 01^{\prime} \mathrm{N}$ and $7^{\circ} 02^{\prime} \mathrm{N}$ and longitudes $5^{\circ} 42^{\prime} \mathrm{E}$ and $5^{\circ} 44^{\prime} \mathrm{E}$ (Fig. 1). It's bounded by major cities and town like Kabba to north, to the east by Benin City, and to the west by Akure. It is accessible by network of tarred and untarred roads. The towns are situated in the humid tropical region of Nigeria, characterized by alternating wet and dry seasons with a mean annual rainfall of over 1500 $\mathrm{mm}$. They are also characterized with a fairly uniform temperature and high relative humidity. The areas are drained by three major rivers Ala, Ogbese and Ose which are seasonal. The rivers dominate the drainage system of 
the study area and it's mainly dendritic. It has an average elevation of about $378 \mathrm{~m}$.

The study area falls within the Precambrian Basement Complex rocks of southwestern Nigeria (Rahaman, 1989). The geological history of the areas is similar to the structural evolutions that had affected the Basement Complex of Nigeria. The study areas are underlain by migmatite-gneiss-quartzite complex of the West African Basement rocks, which forms part of the Pan-African mobile belt. Charnockites, grey gneiss, granite gneiss, porphyritic granite and migmatitic rocks are the predominant rock types in the study area (Fig. 2). Granite gneiss is the metamorphosed granites, widely distributed in the study area and it is of two types; the biotite rich gneiss and the banded gneiss. The biotite rich gneiss is fine to medium grained and show strong foliation trending westwards and is usually dark in colour. The banded gneiss show parallel alignment and alteration. It occurs mostly as hills, boulders and flat lying exposures which are dark to light grey in colour and porphyroblastic in texture. There are several quartzite intrusions cutting across the granite and other felsic and basic rocks.

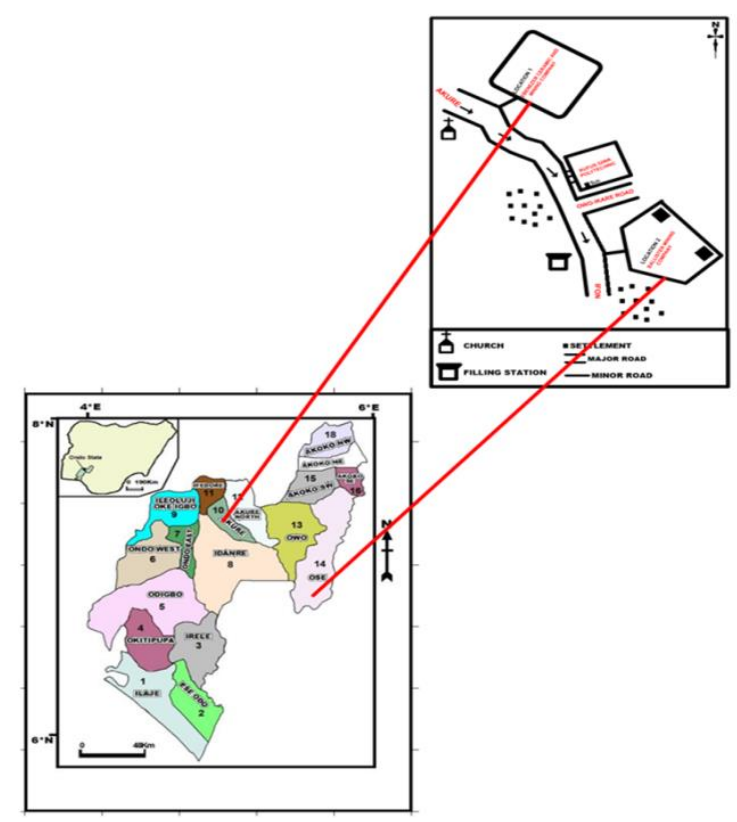

Figure 1: Map of Ondo State showing the location of the study areas.

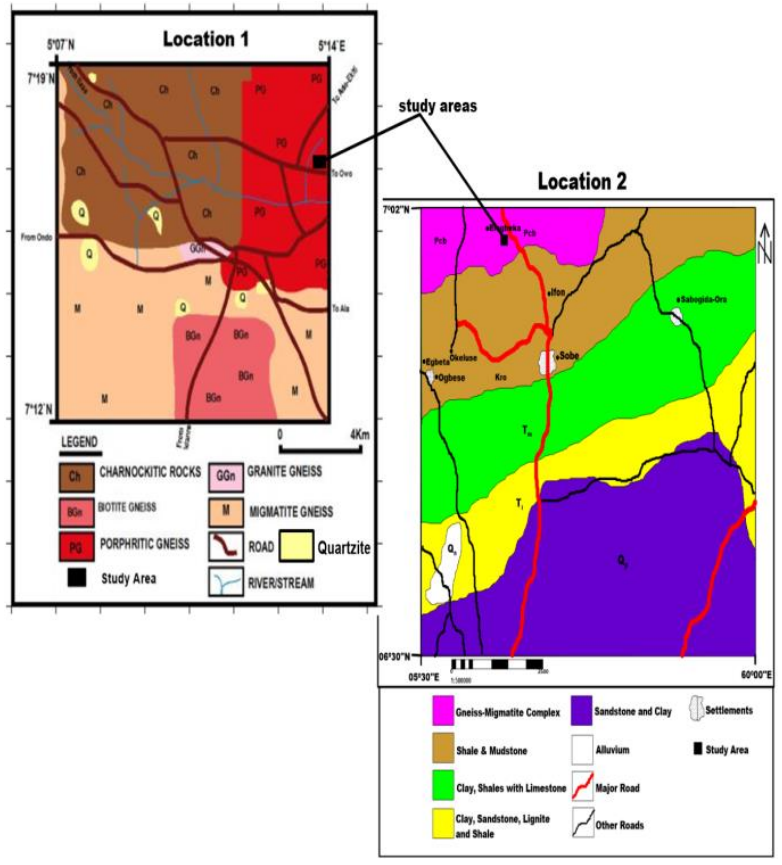

Figure 2: Geological map of the study areas.

\section{MATERIALS AND METHODS}

\subsection{Gamma Survey}

Measurements of radiations from rock aggregates were carried out at the quarries using one of the most cost effective and rapid techniques for geochemical mapping of radioactive elements. The rock aggregates are the coarse rock aggregates obtained from the freshly quarried rock boulders and coarse aggregates obtained from the previously quarried rock boulders. Measurements of the radioactive emission (gamma rays) emanating from the rocks are detected by a spectrometer, which counts the number of times each gamma ray of particular energy intersects it. The energy spectrum measured by the gamma ray spectrometer is in the range $0-3 \mathrm{MeV}$ and energies of geological interest lie between 0.2 and $3 \mathrm{MeV}$. Peaks in the spectrum can be attributed to potassium, thorium and uranium, while the number of gamma ray counts across the whole spectrum is known as Total Count (TC) (Milsom, 2003). The gamma count is a function of the concentration of radioactive elements in rocks.

A highly portable hand held detector Gamma Ray Spectrometer was used for the measurements at 249 different points along eleven traverses (Fig. 3) around the two quarry sites with $5 \mathrm{~m}$ separation between points. The instrument always measures the complete spectrum, from which it evaluates the cps values and calculates the concentrations of elements $\mathrm{K}$ in (\%), eU in (ppm) and eTh in $(\mathrm{ppm})$. The measurements were carried out by positioning the spectrometer at the targeted sample located at varying distance from the quarry sites established by Global Positioning System (GPS). For each measurement, the background radiation level was recorded. Specific levels of activity concentration are related to the geological nature of rocks from which the soils originate. At each point, two readings were taken and the average 
values calculated at each point is considered. The background reading was then subtracted from the mean value to obtain the actual mean radiation levels emitted by each sample. On the site measurements of radiations involve different coarse rock aggregates (coarse aggregates obtained from the freshly quarried rock boulders at the two quarry sites (QF1 and QF2) and coarse aggregates obtained from the previously quarried rock boulders at the two quarry sites (QP1 and QP2). The average values were used for the $\mathrm{K}(\%), \mathrm{U}(\mathrm{ppm})$, Th (ppm), Dose rate, Absorbed Dose rate, Effective Dose rate (outdoor and indoor), annual gonadal equivalent dose and Excess Lifetime Cancer Risk. The results are presented as means and standard deviations, plotted for pictorial view, representation and bar chart illustrations which determine the significant relationships between the radiations from the different types of sample. The results of the Total Count (TC) with their coordinates for all traverses in each locality were imported into Oasis Montaj ${ }^{\mathrm{TM}}$ (Grid and Image tool in Geosoft ${ }^{\circledR}$ software), the total count images were created after micro-levelling the entire data set to remove any apparent residual errors. These images were generated by employing mini-curvature gridding. A Ternary RGB colour models were produced from the software, from which potassium, thorium and uranium were assigned to the green, red and blue respectively because the blue tends to reduce the poorest signal-tonoise ratio of uranium channel.

\subsection{Soil Sample Collection and Preparation}

A total of 20 soil samples were collected from the study areas, 10 samples from each location (Fig. 3). Out of the 10 samples taken from each location, two samples each from four positions were taken at $500 \mathrm{~m}$ away from the quarry sites (Fig. 3). The measurement of radiation from subsurface soils was carried out directly inside the manually dug pits at a depth of $1 \mathrm{~m}$ to $2.0 \mathrm{~m}$. That is, the gamma ray spectrometer was employed in recording insitu the radioactivity measurement at the point of each sample collection to determine the exposure rate due to background radiation. The soils of the study areas are generally lateritic with some clay intercalation. About $2 \mathrm{~kg}$ soil samples were collected in polythene bags and labeled according to the quarry site and location and the GPS coordinates of the locations were recorded. The samples collected were then transported to the laboratory for further processing. The samples were processed following the standard procedures (EML, 1983). The samples were air-dried at room temperature for a week. Then milled and sieved through $2 \mathrm{~mm}$ sieve. They were weighed, sealed and stored in the laboratory for four weeks before being analyzed to ensure secular equilibrium between the various radioactive daughters involved. Proper sealing was ensured by providing double seal to the lid of the container.

\subsection{Gamma Spectrometry and Determination of Activity Concentration}

A gamma spectrometry system was employed in determining the activity concentrations of the radionuclides in the samples. All the samples were counted for 36,000 seconds (10 hours) and the peak areas corresponding to $1460 \mathrm{keV}$ for ${ }^{40} \mathrm{~K}, 352 \mathrm{keV}\left({ }^{214} \mathrm{~Pb}\right)$ for ${ }^{238} \mathrm{U}$, and $583 \mathrm{keV}\left({ }^{208} \mathrm{Tl}\right)$ for ${ }^{232} \mathrm{Th}$ were considered for the estimation of natural radionuclides in all the samples. The integrated counts recorded under the chosen energy peaks were noted for each spectrum. The specific activity concentration of each radionuclide in the samples was obtained using the comparative method of analysis. In this method, the activity concentration of the sample is determined by comparing the relevant peak area in the sample with area of similar photopeak in a reference standard with already known activity concentration.

The activity concentration (C) in $\mathrm{Bq} / \mathrm{kg}$ of the radionuclides in the samples was calculated after decay correction using the expression:

$\mathrm{C}_{\mathrm{s}}(\mathrm{Bq} / \mathrm{kg})=\mathrm{C}_{\mathrm{a}} / \varepsilon_{\gamma} \times \mathrm{M}_{\mathrm{s}} \times \mathrm{t}_{\mathrm{c}} \times \mathrm{P} \gamma$.

Where $\mathrm{C}_{\mathrm{s}}=$ Sample concentration, $\mathrm{C}_{\mathrm{a}}=$ net peak area of a peak at energy, $\varepsilon_{\gamma}=$ Efficiency of the detector for a gamma energy of interest, $M_{s}=$ Sample mass, $t_{c}=$ total counting time, $\mathrm{P}_{\gamma}=$ the abundance of the gamma line in a radionuclide.

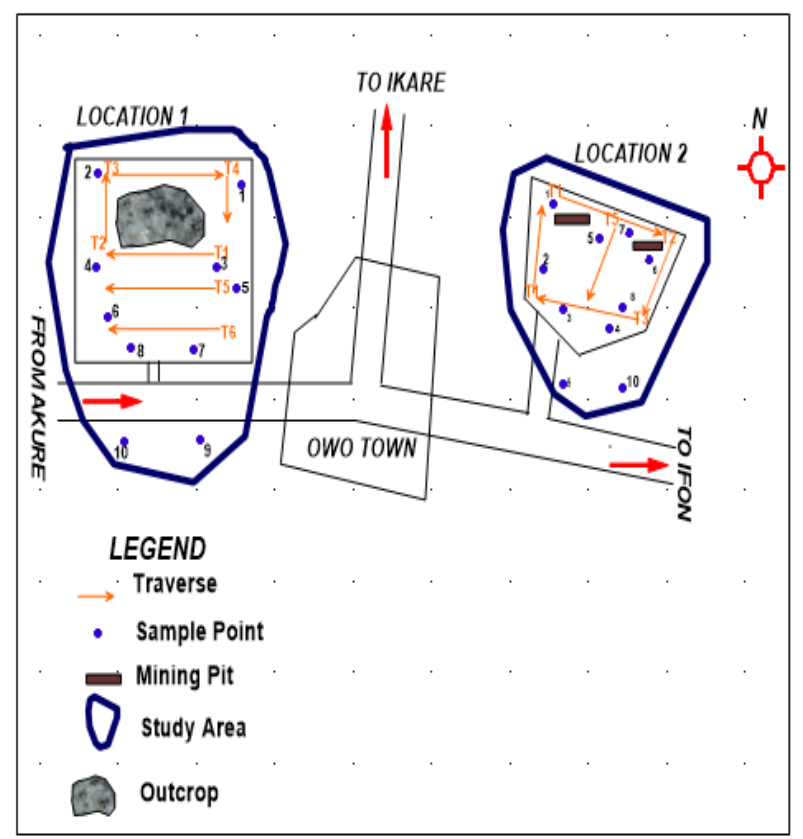

Figure 3: Data acquisition map of the study areas showing radiometric transverses and soil sample points

\subsection{Assessment of Radiation Hazards}

In order to assess the radiological impact of the investigated radionuclides in rock aggregates and the soil samples, the knowledge and estimation of the following radiation hazard parameters (indices) are important.

\subsubsection{Radium equivalent activity $\left(R a_{e q}\right)$}

The radium equivalent activity, $\mathrm{Ra}_{\mathrm{eq}}$ is used to compare the specific activities of materials containing different quantities of ${ }^{238} \mathrm{U},{ }^{232} \mathrm{Th}$ and ${ }^{40} \mathrm{~K}$ and the potential risk assessment associated with the radionuclides is estimated by calculating the radium equivalent activity $\left(\mathrm{Ra}_{\mathrm{eq}}\right)$. It represents a weighted sum of activities of ${ }^{238} \mathrm{U},{ }^{232} \mathrm{Th}$ and ${ }^{40} \mathrm{~K}$. It is based on the assumption that $1 \mathrm{Bqkg}^{-1}$ of ${ }^{238} \mathrm{U}$, $0.7 \mathrm{Bqkg}^{-1}$ of ${ }^{232} \mathrm{Th}$ and $13 \mathrm{Bqkg}^{-1}$ of ${ }^{40} \mathrm{~K}_{\text {produce the same }}$ 
gamma radiation dose rates. The radium equivalent activity index was estimated using equation 1 (Avwiri et al., 2013) as shown in Tables 3 and 4.

$\mathrm{R}_{\mathrm{aeq}}\left(\mathrm{Bqkg}^{-1}\right)=\mathrm{C}_{\mathrm{U}}+1.43 \mathrm{C}_{\mathrm{Th}}+0.077 \mathrm{C}_{\mathrm{K}}$

Where $\mathrm{C}_{\mathrm{U}}, \mathrm{C}_{\mathrm{Th}}$ and $\mathrm{C}_{\mathrm{K}}$ are the activity concentration in $\mathrm{Bqkg}^{-1}$ of ${ }^{238} \mathrm{U},{ }^{232} \mathrm{Th}$ and ${ }^{40} \mathrm{~K}$.

\subsubsection{Air absorbed gamma radiation dose rate}

Absorbed dose is a measure of the energy deposited in a medium by ionizing radiation per unit mass. It may be measured as joules per kilogram and represented by the equivalent S.I unit, gray (Gy) or rad. Effects of gamma radiation are normally expressed in terms of the absorbed dose rate in air, which originate from radioactive sources in the rock aggregates and the soil. The activity concentrations correspond to the total absorbed dose rate in air at $1 \mathrm{~m}$ above the ground level. The absorbed dose rate in air (D) for the workers in the quarry sites and the entire people living within and around the study areas is calculated using equation 2 and shown in Tables 2, 5 and 6. The gamma radiation doses can be estimated by employing the convenient formula (UNSCEAR, 2000).

$\mathrm{D}=\left(0.462 \mathrm{C}_{\mathrm{U}}+0.621 \mathrm{C}_{\mathrm{Th}}+0.0417 \mathrm{C}_{\mathrm{K}}\right) \mathrm{nGyh}^{-1}$

Where: $\mathrm{D}$ is the absorbed gamma dose rates in air (nGyh ${ }^{1}$ ) at $1 \mathrm{~m}$ height above the ground level. $\mathrm{C}_{\mathrm{U}}, \mathrm{C}_{\mathrm{Th}}$ and $\mathrm{C}_{\mathrm{K}}$ represent the activity concentrations of ${ }^{238} \mathrm{U},{ }^{232} \mathrm{Th}$ and ${ }^{40} \mathrm{~K}$ respectively. It is assumed that the contribution from other radionuclides, such as ${ }^{137} \mathrm{Cs},{ }^{235} \mathrm{U},{ }^{87} \mathrm{Rb},{ }^{90} \mathrm{Sr},{ }^{138} \mathrm{La},{ }^{147} \mathrm{Sm}$ and ${ }^{176} \mathrm{Lu}$ to the total dose rate are negligible. UNSCEAR reported that the world average absorbed gamma dose rate mean is $55 \mathrm{nGy} / \mathrm{h}$.

\subsubsection{Annual Gonadal Equivalent Dose (AGED)}

The gonads, the bone marrow and the bone surface cells are considered as organs of interest by UNSCEAR (2000) because of their sensitivity to radiation. An increase in AGED has been known to affect the bone marrow, causing destruction of the red blood cells that are replaced by white blood cells. This situation results in a blood cancer called leukemia. The AGED received by the resident using such material for building can be evaluated by the following equation (Avwiri et al., 2012).

$\operatorname{AGED}(\mu \mathrm{Sv} / \mathrm{y})=3.09 \mathrm{C}_{\mathrm{U}}+4.18 \mathrm{C}_{\mathrm{Th}}+0.314 \mathrm{C}_{\mathrm{K}}$

Where $\mathrm{C}_{\mathrm{U}}, \mathrm{C}_{\mathrm{Th}}$ and $\mathrm{C}_{\mathrm{K}}$ are the radioactivity concentration of ${ }^{238} \mathrm{U},{ }^{232} \mathrm{Th}$ and ${ }^{40} \mathrm{~K}$ in rock aggregates and soil samples.

\subsubsection{Annual Effective Dose Equivalent (AEDE)}

The annual effective dose equivalent (AEDE) received outdoor by a member of the public is calculated from the absorbed dose rate by applying dose conversion factor of $0.7 \mathrm{~Sv} / \mathrm{Gy}$ and occupancy factor for outdoor and indoor was 0.2 and 0.8 respectively (Veiga et al., 2006).

$\operatorname{AEDE}($ Outdoor $)(\mu \mathrm{Sv} / \mathrm{y})=\mathrm{D}\left(\mathrm{nGyh}^{-1}\right) \times \mathrm{T} \times \mathrm{Q} \times 0.2 \times 10^{-}$ 3 .
Where $\mathrm{D}$ is the absorbed dose rate in air, $\mathrm{Q}$ is the conversion factor of $0.7 \mathrm{~Sv} / \mathrm{Gy}$, which converts the absorbed dose rate in air to human effective dose received and $\mathrm{T}$ is the time for one year, i.e. $8760 \mathrm{hrs}$.

Thus, AEDE (Outdoor) $(\mu \mathrm{Sv} / \mathrm{y})=\mathrm{D}\left(\mathrm{nGyh}^{-1}\right) \times 8760(\mathrm{hrs})$ $\times 0.7(\mathrm{~Sv} / \mathrm{Gy}) \times 0.2 \times 10^{-3}$.

AEDE (Indoor) $(\mu \mathrm{Sv} / \mathrm{y})=\mathrm{D}\left(\mathrm{nGyh}^{-1}\right) \times 8760(\mathrm{hrs}) \times 0.7$ $(\mathrm{Sv} / \mathrm{Gy}) \times 0.8 \times 10^{-3}$

The AEDE indoor occurs within a house whereby the radiation risks due to use of the soil and rock as building materials are taken into consideration. AEDE outdoor involves a consideration of the absorbed dose emitted from radionuclide in the environment such as ${ }^{238} \mathrm{U},{ }^{232} \mathrm{Th},{ }^{226} \mathrm{Ra}$ and ${ }^{40} \mathrm{~K}$.

\subsubsection{Representative Gamma Index $\left(I_{\gamma}\right)$}

This is used to estimate the gamma radiation hazard associated with the natural radionuclide in specific investigated samples. The representative gamma index was estimated as follow (Avwiri et al., 2013).

$\mathrm{I}_{\gamma}=\mathrm{C}_{\mathrm{U}} / 150+\mathrm{C}_{\mathrm{Th}} / 100+\mathrm{C}_{\mathrm{k}} / 1500 \leq 1$

Where $\mathrm{C}_{\mathrm{U}}, \mathrm{C}_{\mathrm{Th}}$ and $\mathrm{C}_{\mathrm{K}}$ are the activity concentrations of ${ }^{238} \mathrm{U},{ }^{232} \mathrm{Th}$ and ${ }^{40} \mathrm{~K}$.

The representative gamma index must be lower than unity in order to keep the radiation hazard insignificant.

\subsubsection{Hazard Indices $\left(H_{\text {ex }}\right.$ and $\left.H_{\text {in }}\right)$}

External radiation hazard index $\left(\mathrm{H}_{\mathrm{ex}}\right)$

External radiation hazards due to natural radionuclides of ${ }^{238} \mathrm{U},{ }^{232} \mathrm{Th}$ and ${ }^{40} \mathrm{~K}$ are defined in terms of external or outdoor radiation hazard index, denoted by $\mathrm{H}_{\text {ex. }}$. The external hazard $\left(\mathrm{H}_{\mathrm{ex}}\right)$ and internal hazard $\left(\mathrm{H}_{\mathrm{in}}\right)$ indices were evaluated by the following relations (Ramasamy et al., 2009):

$\mathrm{H}_{\mathrm{ex}}=\mathrm{C}_{\mathrm{U}} / 370+\mathrm{C}_{\mathrm{Th}} / 259+\mathrm{C}_{\mathrm{K}} / 4810 \leq 1$.
$\mathrm{H}_{\mathrm{in}}=\mathrm{C}_{\mathrm{U}} / 185+\mathrm{C}_{\mathrm{Th}} / 259+\mathrm{C}_{\mathrm{K}} / 4810<1$.

Where $\mathrm{C}_{U}, \mathrm{C}_{\mathrm{Th}}$ and $\mathrm{C}_{\mathrm{K}}$ are the radioactivity concentrations of ${ }^{238} \mathrm{U},{ }^{232} \mathrm{Th}$ and ${ }^{40} \mathrm{~K}$ in $\mathrm{BqKg}{ }^{-1}$ respectively.

$\mathrm{H}_{\text {in }}$ should be less than unity for the radiation hazard to be negligible. Internal exposure to radon is very hazardous which can lead to respiratory diseases like asthma (Tufail et al., 2007). Natural radionuclide in soil, rocks and sediment produce an external radiation field to which all humans are exposed. $\mathrm{H}_{\mathrm{ex}}$ must be less than unity for this external radiation hazard to be negligible (Beretka and Mathew, 1985). $\mathrm{H}_{\mathrm{ex}}$ equal to unity corresponds to the upper limit of radium equivalent dose $\left(370 \mathrm{Bqkg}^{-1}\right)$ (Beretka and Mathew, 1985).

\subsubsection{Excess Lifetime Cancer Risk (ELCR)}

This is the probability of developing cancer over a lifetime at a given exposure level, considering 70 years as the average duration of life for human being. The Excess 
Lifetime Cancer Risk (ELCR) was calculated using the following equation (Taskin et al., 2009).

$\mathrm{ELCR}=\mathrm{AEDE} \times \mathrm{DL} \times \mathrm{RF}$

Where AEDE is the Annual Equivalent Dose Equivalent, $\mathrm{DL}$ is the average duration of life (estimated to 70 years) and $\mathrm{RF}$ is the Risk Factor $\left(\mathrm{Sv}^{-1}\right)$, i.e. fatal cancer risk per Sievert. For stochastic effects, ICRD uses RF as 0.05 for public (Taskin et al., 2009).

\subsection{Conversions}

The elemental concentrations of uranium-238 (ppm), Thorium-232 (ppm) and potassium-40 (\%) can be calculated from measured activity concentrations of ${ }^{238} \mathrm{U}$, ${ }^{232} \mathrm{Th}$ and ${ }^{40} \mathrm{~K}$ in $\mathrm{Bqkg}^{-1}$ using conversion factors recommended by the IAEA, 2003 as follows:

$$
1 \mathrm{ppm}=10^{-4} \%
$$

$1 \% \mathrm{~K}=313 \mathrm{Bqkg}^{-1}$ of ${ }^{40} \mathrm{~K}$.

$1 \mathrm{ppm} \mathrm{U}=12.35 \mathrm{Bqkg}^{-1}$ of ${ }^{238} \mathrm{U}$

$1 \mathrm{ppm} \mathrm{Th}=4.06 \mathrm{Bqkg}^{-1}$ of ${ }^{232} \mathrm{Th}$

In recent years, the SI (System International) units used in radiation protection are the Gray (Gy) and the Sievert (Sv). The Gray is the unit of absorbed dose corresponding to the $\mathrm{rad}$ and is the energy imparted by ionizing radiation to material corresponding to one joule $/ \mathrm{kg}$, while the Sievert is the unit of dose equivalent corresponding to the rem.

\section{RESULTS AND DISCUSSION}

Granite rocks are older granite suite of the Basement Complex rocks known to be associated with elevated levels of naturally occurring radionuclides and emit ionizing radiation to the environment of the quarry. Thus, workers and residents around such site are liable to radiation exposure. Due to this, it is important to measure the rates of radiation exposure around quarry sites to safe lives of this category of people.

The radiometric data around the quarry sites are summarized in terms of colour images (radiometric images) obtained from minimum curvature grids. Figures 4 and 5 show the radiometric data in terms of Total Count (TC) which is a measure of total radioactivity over the spectrum. The images shown use an equal-area normalization of the colour scale. The data indicate the composite radiogenic activity of the formations around the quarry sites. It is evident that there is a significant geological control of the radiometric responses observed. The contributions from the three radioelements; potassium, uranium and thorium are summarized in the ternary image (Figs. $4 \mathrm{~d}$ and $5 \mathrm{~d}$ ). The ternary image is a normalized (to an equal-area histogram) 3-way colour stretching of the contributions from the individual radioelements. The presentation is a standard method in radiometric processing and interpretation (IAEA, 1991). In areas where all three radioelements concentrations are low, the ternary image shows black, when all the three concentrations are high, the ternary response tends to white. The three radiogenic elements highs and lows in the ternary image are also reflected in the high and low zones within the Total Count (TC) images. From the ternary map, the weathered rock can easily be delineated as having low concentration of the three radiogenic elements (depicted by a black colour in Figs. 4d and 5d).

\subsection{Radiometric Maps (Location One)}

In order to have better understanding of the distribution and distinctness of the different level of radiations emitted from the rock types in the study areas, image maps and ternary characters of the radioelements $(\mathrm{K}, \mathrm{U}$ and $\mathrm{Th})$ are shown in Figs. 4 and 5.

\subsubsection{Potassium map}

The potassium, K map (Figure 4a) shows different degrees of potassium concentrations that reflect different lithological units and alterations in the area. Potassium radiation fundamentally comes from potash feldspars, which are mainly common in felsic igneous rocks (e.g. granite) and are low in mafic rocks (e.g. basalts and andesite) (Gunn et al., 1997b). Rock alterations can also result in high K concentrations (Wilford et al., 1997). A number of potassium anomalies are evident in the radiometric image Fig. 4a. The blue colour corresponds with low $\mathrm{K}$ values while the pink corresponds with very high $\mathrm{K}$ values. The colour red represents moderately high to high $\mathrm{K}$ values and the shades of orange to yellow colour are associated with moderately low $\mathrm{K}$ values. Low potassium concentration is observed at the southeastern (E) part of the image, similar observation is seen around the central part of the image (G, H, D) and a fairly low concentration is also observed in the southwestern part $(\mathrm{G})$ of the map. This Low concentration might be as a result of the type of soil within this region which is lateritic soil with clay intercalations with high water retaining capacity. This tends to shield the potassium radiation from the underlying rocks hence, reducing the intensity of the signal at that point. Since radiometric survey uses the assumption that residual soil of top $30 \mathrm{~cm}$ is able to absorb most of the radiated radioactive element from the underlying rocks or the lithology. To justify this, the fairly low concentration observed on the southwestern part of the image corresponds to the mining phase, hence does not contain much water to release to the surrounding. The low $\mathrm{K}$ in location 1 could be attributed to the geologic materials in the lineaments and also as a result of the ore body present in the environment. High concentration of potassium is also observed at the northwestern and southwestern parts of the Location (Fig. 4a). 


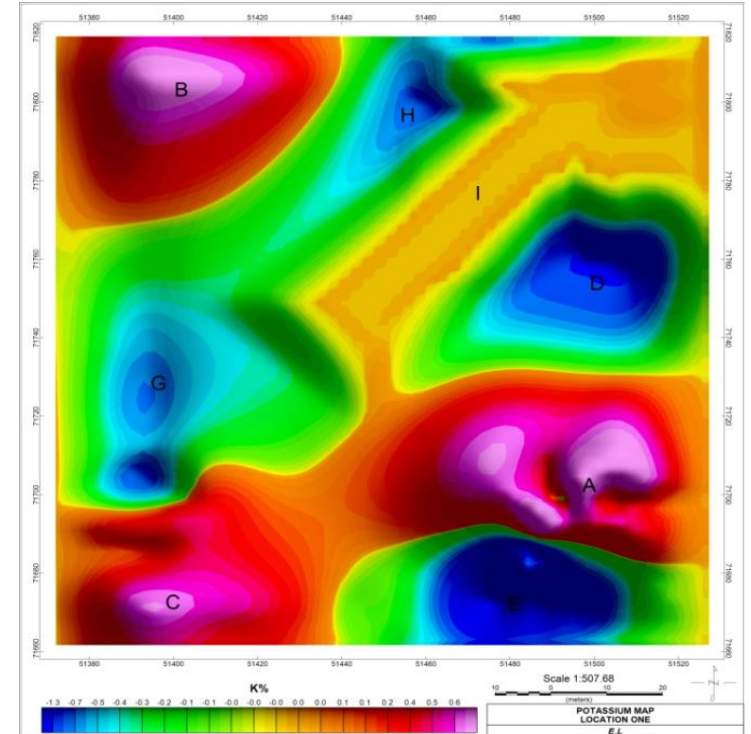

Figure 4a: Map showing the concentration of potassium in entire area of Location 1

\subsubsection{Thorium map}

The thorium map shows three distinct regions of thorium concentration in the area. The pink colour represents high concentration of the thorium and low thorium concentration represented by blue colour (Figure $4 b$ ). The high concentration in thorium depicted A (Figure 4b) corresponds to acid intrusive rock in the area. An enrichment of thorium may be indicative of alteration of natural processes in the areas. In addition, the low concentration of Th $(\mathrm{E}, \mathrm{H}, \mathrm{I}, \mathrm{J}, \mathrm{K})$ observed towards the northern and southern parts on the Th map of the area coincides with the weathered rocks in the area. This indicates the fact that the water body shields the emission of radiation from radiogenic element (thorium) of the underlying lithology.

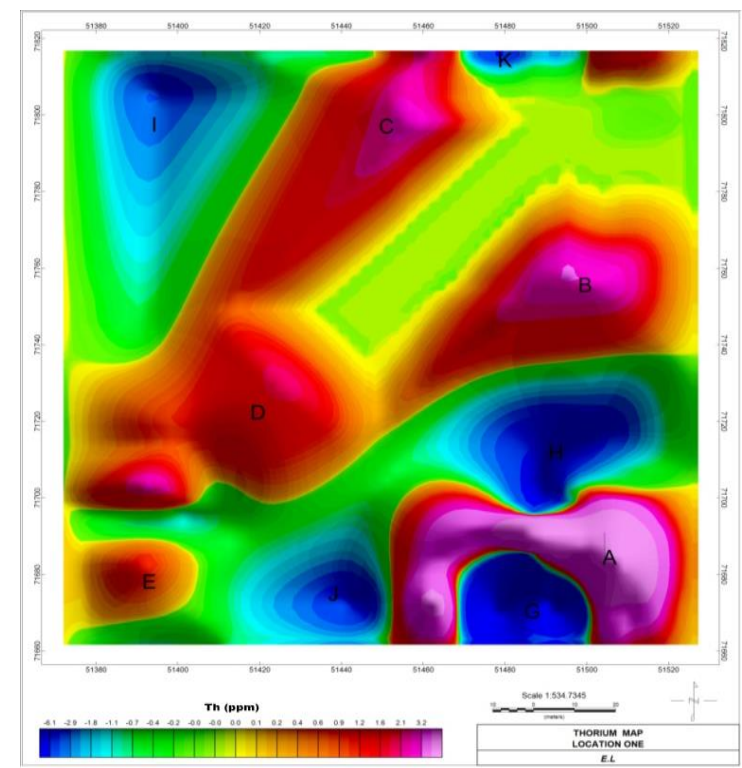

Figure 4b: Thorium concentration map of Location 1

\subsubsection{Uranium map}

The uranium image shows good definition in mapping felsic rock, highest content of silicon with predominance of quartz, alkaline feldspar e.g granite, rhyolite and weathered sediments (radiogenic pattern $\mathrm{D}$ and $\mathrm{H}$ in Fig. 4c) and certain radiogenic rock pattern A, B and G. The feature marked $\mathrm{A}$, registered high uranium concentration. High concentration of uranium is also observed at the northeastern and southeastern parts of the area, and fairly low concentration of uranium at the northwestern part of the map. This feature coincides with granite in the area. Thus the granite is broadly represented by high $\mathrm{U}$ concentration. Unlike the $\mathrm{K}$ and $\mathrm{Th}$ maps, the uranium map could not clearly delineate the distinct boundary between most of the lithology of the area. At the eastern part of the map in (Figure 4c), there exists noticeable halos. This halo is attributed to rock alteration like weathering in that region. The low $\mathrm{U}$ in the study area is also as a result of the underlying geology attributed to the area.

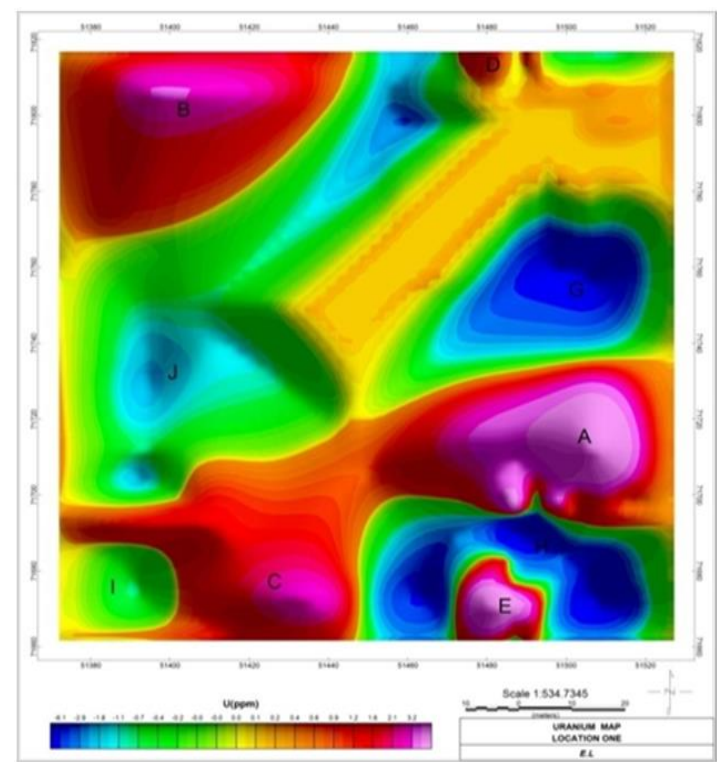

Figure 4c: Uranium concentration map of Location 1

\subsubsection{Ternary Map}

The ternary map of K- eTh- eU parameters (Fig. 4d) shows interaction of three radionuclides in the definition of the contacts of the map and the borders of the nucleus. Green indicates predominance of Thorium over the other two radioelements. Low concentrations of $\mathrm{U}$, Th, and $\mathrm{K}$ radioactive elements are displayed by black colours, with the magenta colour (A and $G$ ) corresponding to high potassium with low uranium and thorium concentrations, this is observed at the central part of the image. Those with the low content of $\mathrm{K}$ but high contents of $\mathrm{U}$ and $\mathrm{Th}$ are represented by green colour (B, H and I) and the yellow colour (D) are characterized by high potassium and thorium with low uranium. Additionally, the blue colour (C) corresponds to regions of high uranium with low potassium and thorium and white colour corresponds to high potassium, uranium and thorium. From the ternary map, the weathered rock was delineated as having 
low concentration of the three radiogenic elements (depicted by a black colour in Fig. 4d). The high concentration of $\mathrm{K}$, Th and $\mathrm{U}$ (A) of western part of the image coincides with granite unaltered in the area. The high $\mathrm{K}$ with low $\mathrm{U}$ and Th concentration which is depicted by a magenta colour coincides with granitic rock. Blue colour corresponds to regions of high uranium with low potassium and thorium which may be attributed to unearthed intrusive igneous rock in the area.

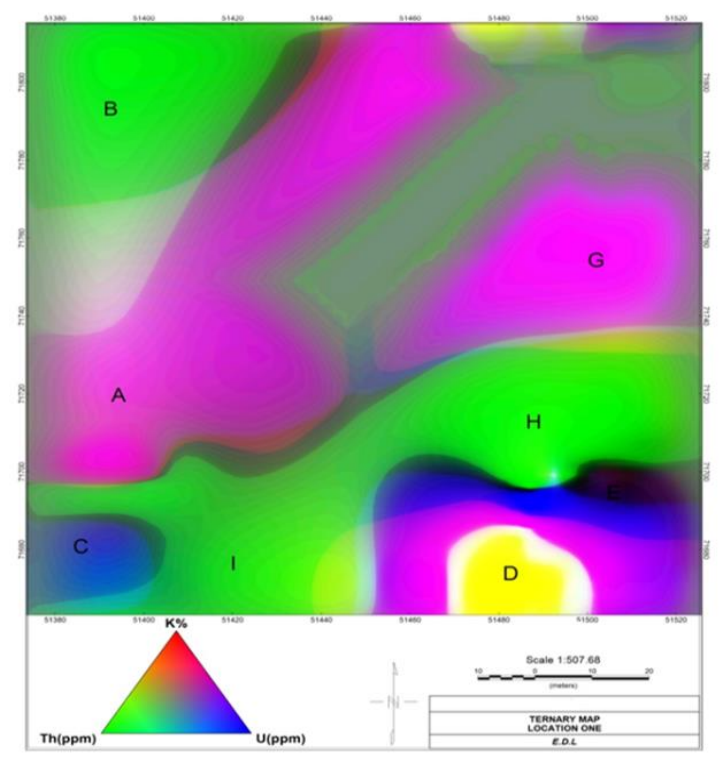

Figure 4d: Ternary map of Location 1

\subsection{Radiometric Maps (Location Two)}

\subsubsection{Potassium map}

Areas of high values of potassium are due to mineralogical compositions of the rocks as observed in the northeastern part of the map (A) (Fig. 5a), where a homogeneous gamma spectrometric pattern is noticed. The low concentration of potassium in the rocks of the study area is due to their basic composition. The low values of potassium are interpreted as been related to altered rock, which is an indication of loss of potassium due to weathering. High potassium values in the northeastern region of the map are observed along an alignment AA probably related to a fault.

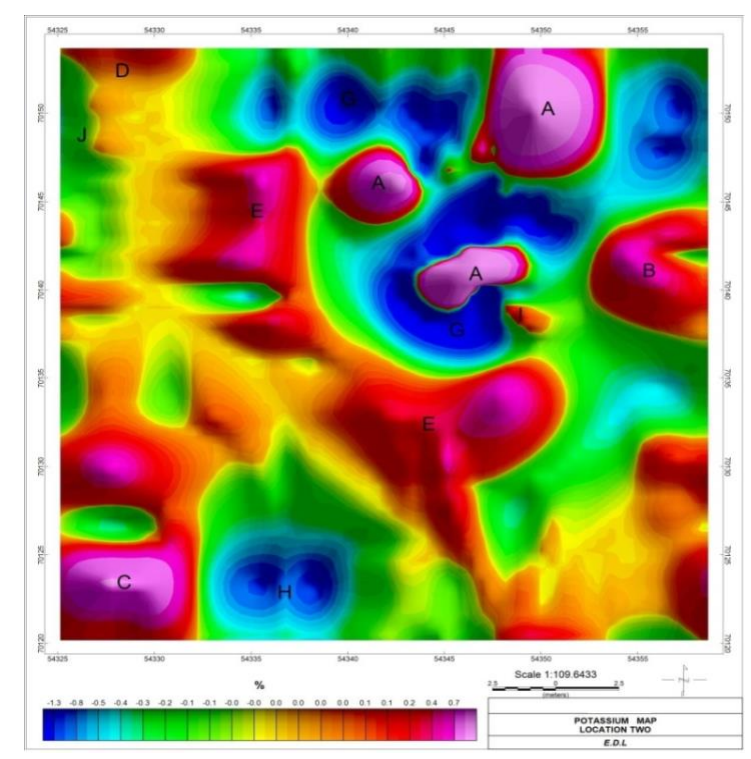

Figure 5a: Map showing the concentration of potassium in Location 2

\subsubsection{Thorium map}

Thorium tends to be restricted to clays colloids and iron oxides forming anomalous concentration without any geological correlation. Anomalies in the thorium, maps the lithology and lithological boundaries of the area. The thorium (Th) map shows three distinct regions of thorium concentration in the area. Relatively high concentrations of Th are represented by pink colour and low Th concentrations are represented by blue colour (Fig. 5b). The high concentration in Th depicted (A) in southwestern, (B) in northeastern region of the map (Fig. $5 \mathrm{~b}$ ) is attributed to the absence of undeformed potassic feldspar minerals in the area. This could also have resulted from the terrestrial gamma radiation or due to incorporated minerals from the surrounding rocks. Moreover, the low concentration of $\mathrm{Th}(\mathrm{G}, \mathrm{M})$ observed at the northern region of the map and $(\mathrm{K}, \mathrm{I})$ southwestern part of the area coincides with the biotite and weathered rocks in the area. This indicates that the water-body shields the emission of radiation from radiogenic element (thorium) of the underlying lithology. This also indicates that the rock/residual soil has low terrestrial gamma radiation or emission due to geologic processes. 


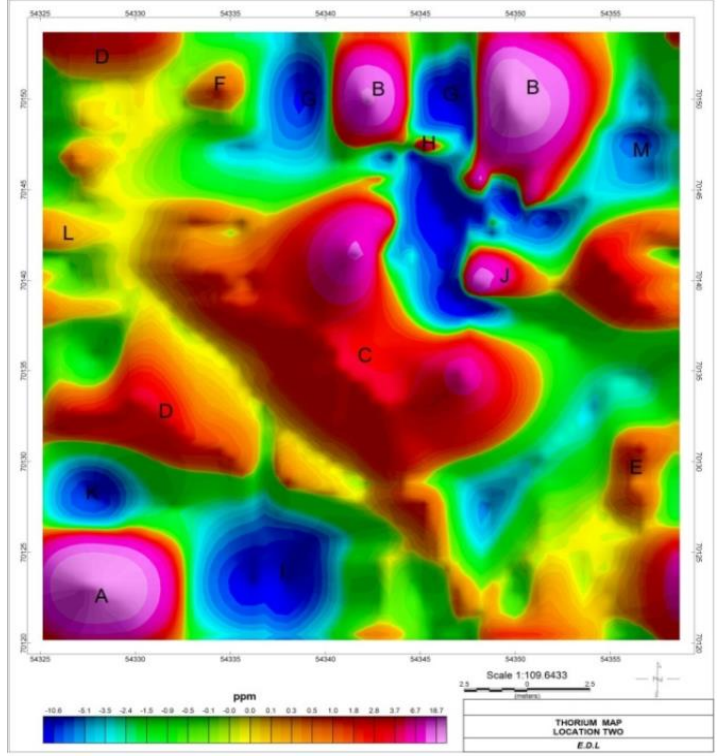

Figure 5b: Map showing the concentration of thorium in Location 2

\subsubsection{Uranium map}

High concentration of uranium towards the northern part (Fig. 5c) is interpreted as an indication of areas sufficiently concentrated in clays and iron oxides. Areas of intermediate uranium value can be observed in southern part of the area of Location 2. Enriched zones can be related to deformation processes in which uranium-rich fluid are mobilized. Figure 5c shows great variability of uranium grades, probably because of pedogenetic phenomena.

\subsubsection{The Ternary Image}

The ternary map of K- eTh- eU parameters (Fig. 5d) shows interaction of three radionuclides in the definition of the contacts of the map. The ternary radiometric map (Fig. 5d) shows different colour combinations which indicate the $\mathrm{K}$, Th and $U$ concentrations. Low concentrations of $U$, Th, and $\mathrm{K}$ radioactive elements are displayed by black colours with the magenta colour (C) corresponding to high potassium with low uranium and thorium concentrations. Those with the low content of $\mathrm{K}$ but high contents of $\mathrm{U}$ and Th are represented by green colour $(\mathrm{H})$ and the yellow colours (C) are characterized by high potassium and thorium with low uranium. Additionally, the blue colour (E) corresponds to regions of high uranium with low potassium and thorium and white (D) colour corresponds to high potassium, uranium and thorium. From the ternary map, the areas with low concentration of the three radiogenic elements depict altered rocks due to the fact that radiogenic elements lose their concentration due to alteration (Fig. 5d). The high concentration of K, Th and $\mathrm{U}$ (portions marked by A) in the northeastern part of the ternary image coincides with unweathered granitic rock in the area. The high $\mathrm{K}$ with low $\mathrm{U}$ and $\mathrm{Th}$ concentration which is depicted by a magenta colour can be attributed to the fact that some areas around the quarry site have not been exploited, that is, quarry activities which involve bringing the naturally occurring radioactive materials to the surface have not taken place. This can be corroborated with the presence of some local indigenous tress found within the areas. Blue colour corresponds to regions of high uranium with low potassium and thorium which may be attributed to felsic schist- highly sheared granite in the area. Generally, the variation in the radioactivity of the study areas could be attributed to the rock types, especially low concentration is due to weathered nature/mineralogical compositions of the rocks. Also, the variations are always associated to acidic intrusive and metamorphosed rocks.

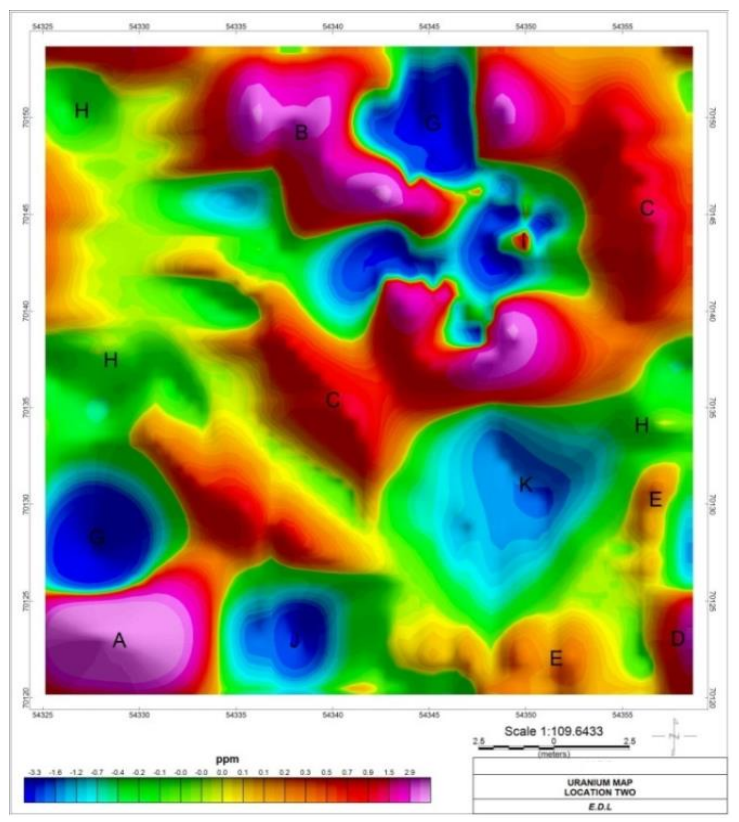

Figure 5c: Uranium concentration map of Location 2

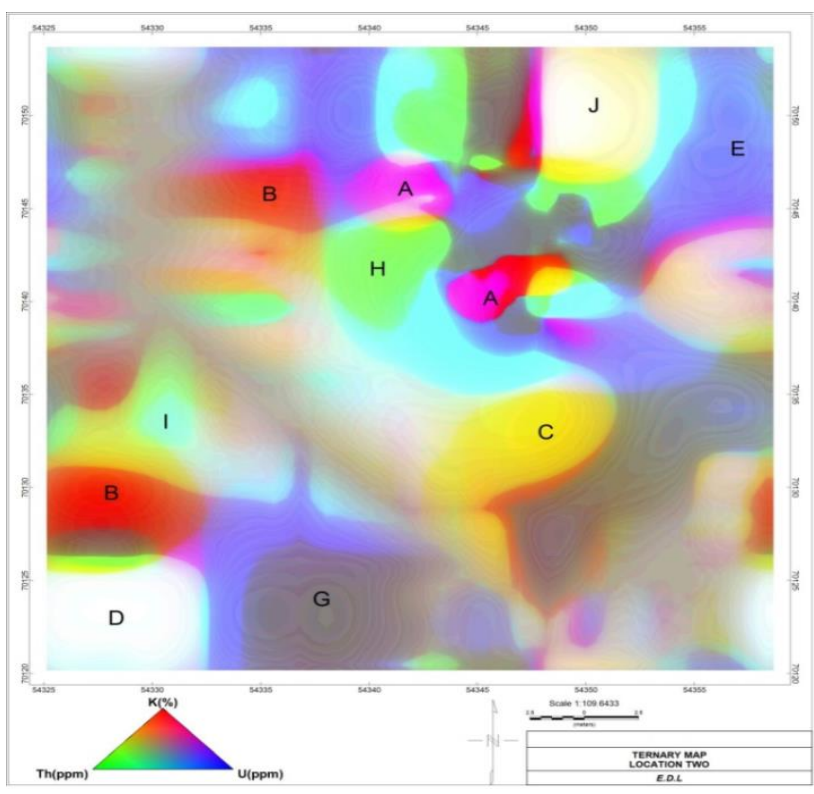

Figure 5d: Ternary map of Location 2

Investigations have shown that levels of radiations vary considerably based on soils, rock types and also in the types of radioisotopes. High radiation levels from natural radionuclide have been associated with granitic and silicic igneous rocks like those in the study area (Brimhal and 
Adams, 1982). It is therefore possible that the measured radiation from the study areas are from the natural radionuclides like ${ }^{238} \mathrm{U},{ }^{232} \mathrm{Th}$ and ${ }^{40} \mathrm{~K}$ which are the radioisotopes associated with igneous rocks. These rocks have been observed to be more radioactive than the metamorphic rocks (Brimhal and Adams, 1982). The radiation levels in the recently quarried coarse aggregate rocks at the quarry sites of Locations 1 and 2 (QF1 and QF2) are $372 \mathrm{cps}$ and $382 \mathrm{cps}$ (Table 1) with absorbed dose rates of $9.14 \mathrm{nGy} / \mathrm{hr}$ and $7.31 \mathrm{nGy} / \mathrm{hr}$ (Fig. 6) and annual effective dose rate of $11.21 \mu \mathrm{Sv} / \mathrm{yr}$ and $8.97 \mu \mathrm{Sv} / \mathrm{yr}$ (Table 2). Similarly, the radiation levels in the previously quarried coarse aggregate at the quarry sites of Locations 1 and 2 (QP1 and QP2) with absorbed dose rates and their annual effective dose rates are $365 \mathrm{cps}$ and $377 \mathrm{cps}$ (Table 1), $6.08 \mathrm{nGy} / \mathrm{hr}$ and $3.16 \mathrm{nGy} / \mathrm{hr}$ and $7.45 \mu \mathrm{Sv} / \mathrm{yr}$ and 3.87 $\mu \mathrm{Sv} / \mathrm{yr}$ respectively (Table 2 ). The values of radiation of coarse aggregates obtained from the freshly quarried rock boulders (QF1 and QF2) and the previously quarried rock boulders (QP1 and QP2) at the two quarry sites were compared. It was observed that the values of radiations in the recently quarried coarse aggregate rocks are higher than the previously quarried coarse aggregate (Table 1 ). The higher values of radiation in the recently quarried coarse aggregate rocks at the quarry sites compared with the previously quarried coarse aggregate rocks are indicative of the fact that the radionuclides are resident in the parent rock materials. The mean absorbed dose measured ranged from $3.16 \mathrm{nGy} / \mathrm{hr}$ to $9.14 \mathrm{nGy} / \mathrm{hr}$. The highest absorbed dose rate was recorded in recently quarried coarse aggregate rocks at the quarry site of Location 1, while, the least dose rate was obtained in previously quarried coarse aggregate rocks at the quarry site of Location 2 (Fig. 6). The mean values are lower than the world average value of $55 \mathrm{nGy} / \mathrm{hr}$ (Fig. 6). The corresponding outdoor and indoor mean annual effective doses ranged from $3.87 \mu \mathrm{Sv} / \mathrm{yr}$ to $11.21 \mu \mathrm{Sv} / \mathrm{yr}$ and 15.50 $\mu \mathrm{Sv} / \mathrm{yr}$ to $44.84 \mu \mathrm{Sv} / \mathrm{yr}$ (Table 2, Figs. 7 and 8 ). The values of outdoor and indoor annual effective dose equivalent in this study is far below the worldwide average annual effective dose equivalent values of $70 \mu \mathrm{Sv} / \mathrm{yr}$ for outdoor and $450 \mu \mathrm{Sv} / \mathrm{yr}$ for indoor annual effective dose equivalent (Figs 7 and 8). The results obtained for the annual gonad equivalent dose (AGED) (21.75 mSv/yr to $63.02 \mathrm{mSv} / \mathrm{yr}$ ) and the excess lifetime cancer risk (ELCR) (0.014 to 0.039) (Table 2 and Fig. 9) are below the permissible values of $300 \mathrm{mSv} / \mathrm{yr}$ and $0.29 \times 10^{-3}$ respectively (UNSCEAR, 2000). This implies that the gonadal values may pose no threat to the bone marrow and the bone surface cells of the workers and the general populace around the study areas.

The excess lifetime cancer risk estimated from the annual effective dose (Table 2) in the quarry sites fall below the world weighted average (Fig. 9) indicates that the probability of the workers and the people living around the vicinity to develop extra cancer due to exposure to natural radioactivity is insignificant right now, however, continuous accumulation may pose radiological health risks to the people living in the areas in future. Also, the calculated values of the external hazard index, internal hazard index and representative gamma index for rock aggregates studied are less than the world permissible value of unity (Fig. 9). This is an indication that the rock aggregates produced from these quarries will not introduce any respiratory tract disease such as asthma and other external diseases such as skin cancer, erythema and cataracts to the workers involved in quarry activities and users of such rock aggregates. Relatively higher value of radiations in coarse aggregates of porphyritic granite gneiss compared with the coarse aggregates of fine to medium grained banded gneiss in this study implies that fine to medium grained rocks absorb and reflect radiation easily than rocks of predominantly coarse grains. This shows that radionuclide distribution in rocks is influenced by grain size distribution. The study also shows that thorium has the highest contribution to the total absorbed dose in rock aggregates of the study areas.

Table 1: Total Mean Values of Radionuclides from Rock Aggregates from the Quarry Sites Environment

\begin{tabular}{lllllll}
\hline $\begin{array}{l}\text { Location } \\
\text { Code }\end{array}$ & Sample & $\begin{array}{l}\text { Mean } \\
(\%)\end{array}$ & $\begin{array}{l}\text { Mean U } \\
(\mathrm{ppm})\end{array}$ & $\begin{array}{l}\text { Mean Th } \\
(\mathrm{ppm})\end{array}$ & $\begin{array}{l}\text { Mean Total } \\
\text { Count }(\mathrm{cps})\end{array}$ & Dose Rate \\
\hline QF1 & 1.03 & 2.3 & 13.3 & 371.7 & 59.8 \\
QP1 & 0.40 & 2.4 & 8.2 & 364.7 & 39.6 \\
QF2 & 3.85 & 1.1 & 11.0 & 382.2 & 84.4 \\
QP2 & 4.66 & 2.1 & 3.3 & 376.7 & 81.6 \\
\hline
\end{tabular}

Table 2: Radiation Hazard parameters for rock aggregates

\begin{tabular}{lllllllll}
\hline $\begin{array}{l}\text { Sample } \\
\text { Code }\end{array}$ & $\begin{array}{l}\text { Mean Absorbed } \\
\text { Dose Rate (D) } \\
(\mathrm{nGy} / \mathrm{hr})\end{array}$ & $\begin{array}{l}\text { AEDE (outdoor) } \\
(\mu \mathrm{Sv} / \mathrm{yr})\end{array}$ & $\begin{array}{l}\text { AEDE } \\
(\text { indoor }) \\
(\mu \mathrm{Sv} / \mathrm{yr})\end{array}$ & $\begin{array}{l}\text { AGED } \\
(\mathrm{mSv} / \mathrm{yr})\end{array}$ & $\begin{array}{l}\text { ELCR } \\
\left(\times 10^{-3}\right)\end{array}$ & $\mathrm{H}_{\mathrm{ex}}$ & $\mathrm{H}_{\text {in }}$ & $\mathrm{I}_{\gamma}$ \\
\hline QF1 & 9.14 & 11.21 & 44.84 & 63.02 & 0.039 & 0.058 & 0.064 & 0.149 \\
QP1 & 6.08 & 7.45 & 29.83 & 41.82 & 0.026 & 0.038 & 0.045 & 0.098 \\
QF2 & 7.31 & 8.97 & 35.86 & 50.59 & 0.031 & 0.046 & 0.049 & 0.120 \\
QP2 & 3.16 & 3.87 & 15.50 & 21.75 & 0.014 & 0.019 & 0.025 & 0.050 \\
\hline
\end{tabular}




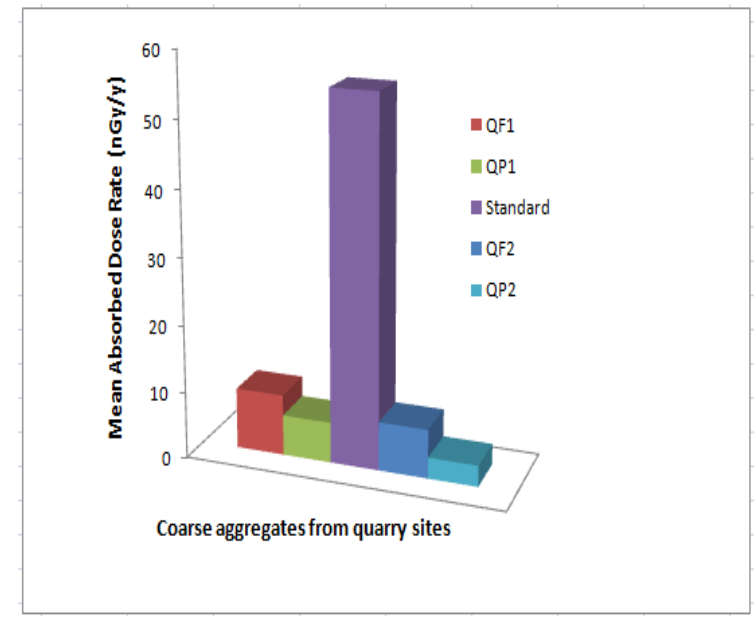

Figure 6: A comparison of the absorbed dose rate (nGy/h) in the study area. $\mathrm{S}$ is the standard threshold limit by UNSCEAR (2000)

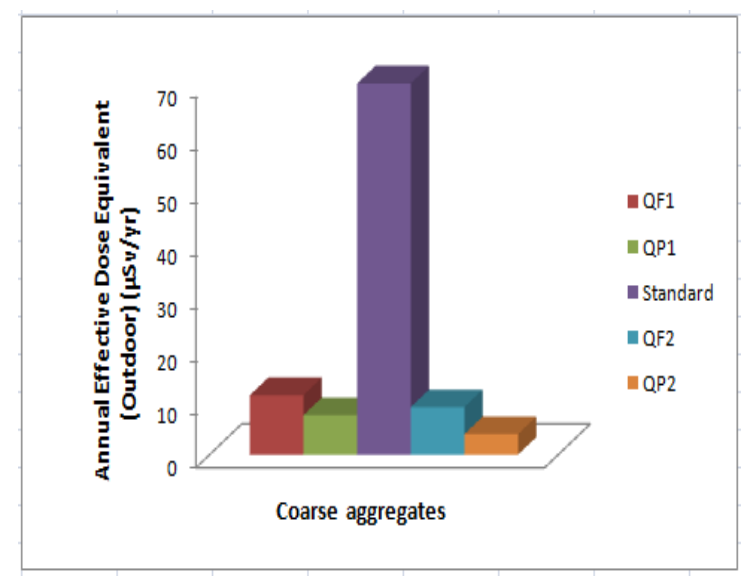

Figure 7: A comparison of the Annual Effective Dose Equivalent (outdoor) (AEDE) in coarse aggregates with the UNSCEAR, 2000

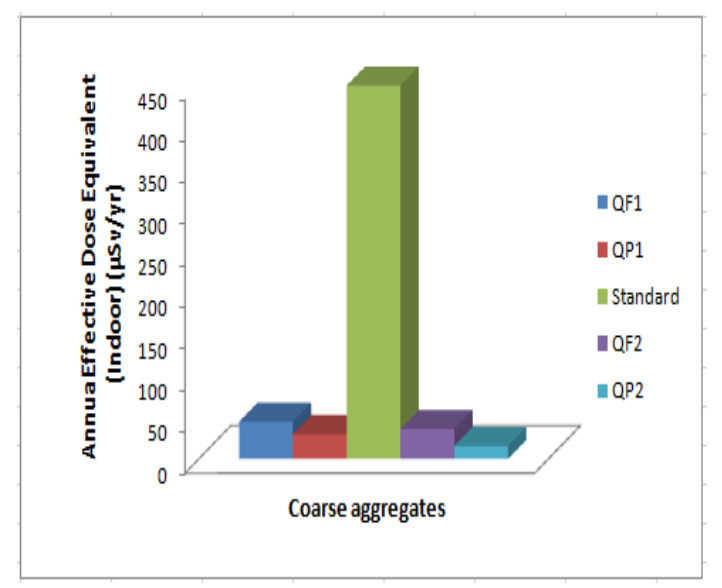

Figure 8: A comparison of the Annual Effective Dose Equivalent (indoor) (AEDE) in coarse aggregates with the UNSCEAR, 2000

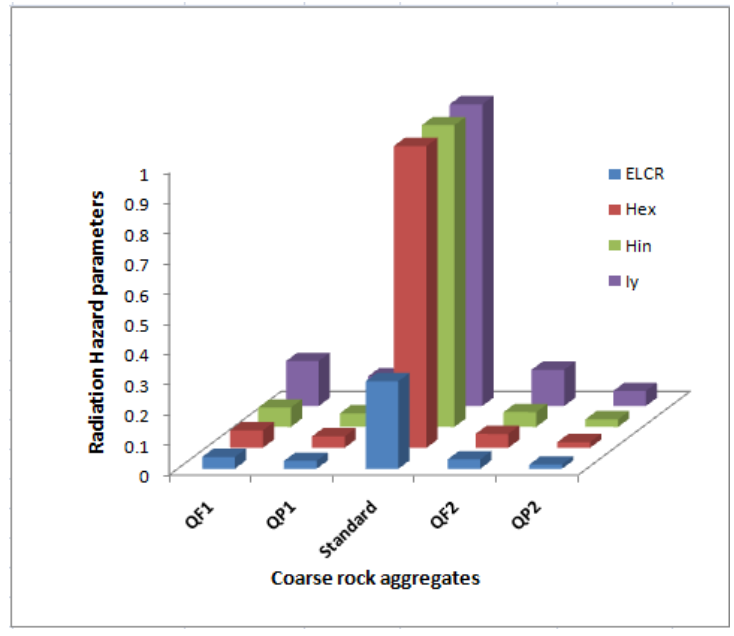

Figure 9: Excess Lifetime Cancer Risk, External hazard index, Internal hazard index and Gamma

Representative Index in coarse rock aggregates of the study area as compared with the UNSCEAR, 2000.

The results of gamma-ray measurements of ${ }^{238} \mathrm{U},{ }^{232} \mathrm{Th}$ and ${ }^{40} \mathrm{~K}$ activity concentrations of the quarries soil samples with their radium equivalent activity are given in Tables $3 \mathrm{a}$ and $4 \mathrm{a}$, while that at $500 \mathrm{~m}$ away from the quarries are given in Tables $3 \mathrm{~b}$ and $4 \mathrm{~b}$ (Fig. 10). The activity concentrations vary from site to site, which indicates a large variation in chemical and mineralogical properties of soil samples. Activity concentrations are in the order ${ }^{232} \mathrm{Th}$ $<{ }^{238} \mathrm{U}<{ }^{40} \mathrm{~K}$. The mean radioactivity concentration values of ${ }^{232} \mathrm{Th},{ }^{238} \mathrm{U}$ and ${ }^{40} \mathrm{~K}$ are $0.0027 \pm 0.0003 \mathrm{~Bq} / \mathrm{kg}$ and $0.0036 \pm 0.00036 \quad \mathrm{~Bq} / \mathrm{kg}, \quad 0.028 \pm 0.0012 \quad \mathrm{~Bq} / \mathrm{kg}$ and $0.026 \pm 0.0012 \mathrm{~Bq} / \mathrm{kg}$ and $47.45 \pm 0.0313 \mathrm{~Bq} / \mathrm{kg}$ and $69.42 \pm 0.0313 \mathrm{~Bq} / \mathrm{kg}$ respectively for soils within the quarries of Locations 1 and 2 (Tables 3a and 4a). At 500 $\mathrm{m}$ away from the quarry sites, the mean values are $0.0008 \pm 0.75 \mathrm{~Bq} / \mathrm{kg}$ and $0.0049 \pm 0.0004 \mathrm{~Bq} / \mathrm{kg}$, $0.020 \pm 0.0012 \mathrm{~Bq} / \mathrm{kg}$ and $0.052 \pm 0.0012 \mathrm{~Bq} / \mathrm{kg}$ and $41.54 \pm 0.0313 \mathrm{~Bq} / \mathrm{kg}$ and $200.32 \pm 0.0313 \mathrm{~Bq} / \mathrm{kg}$ respectively for the quarries (Tables $3 \mathrm{~b}$ and $4 \mathrm{~b}$ ). The result shows that the activity concentration within the quarry site of Location 1 is higher than that at $500 \mathrm{~m}$ away from the quarry. This could be as a result of temperature, elevation difference and radioactive half-lives, while, the result of Location 2 shows that the activity concentration at $500 \mathrm{~m}$ away is higher than the activity concentration within the quarry site as shown in Fig. 10. Although, these activity concentration values obtained in these locations and their environs are below the world permissible value of 30.0 $\mathrm{Bq} / \mathrm{kg}$ for ${ }^{232} \mathrm{Th}, 35.0 \mathrm{~Bq} / \mathrm{kg}$ for ${ }^{238} \mathrm{U}$ and $400.0 \mathrm{~Bq} / \mathrm{kg}$ for ${ }^{40} \mathrm{~K}$ (UNSCEAR, 2000) (Fig. 10). Change in the soil activity with location depends on the soil physical and chemical properties which are common phenomenon in any appraisal of radiation in the environment. The spatial distribution of the radionuclides across the two locations revealed that the concentration of ${ }^{40} \mathrm{~K}$ was highest even at the neighbouring settlement, making ${ }^{40} \mathrm{~K}$ the dominant radionuclide in the areas (Fig. 10). The relatively high values of ${ }^{40} \mathrm{~K}$ could be as a result of feldspathic characterization of rock formation of the study areas. ${ }^{238} \mathrm{U}$ and ${ }^{232} \mathrm{Th}$ has the lowest concentration. The low concentrations especially in some places of the study areas can be attributed to the presence of some local indigenous 
trees around the sites, which shows that those areas have not been exploited. This corroborated with the result of the radiometric maps generated from the measurements of different points along eleven traverses around the study areas. Radium equivalent activity ( $\mathrm{Ra}$ eq) owing to activity concentration of the three natural radionuclides from the two sites varies from 0.70 to $28.94 \mathrm{~Bq} / \mathrm{kg}$. These values are below the world standard of $370 \mathrm{~Bq} / \mathrm{kg}$ (Fig. 10).

The estimated absorbed dose rates in all the soils investigated ranged from $0.38 \mathrm{nGy} / \mathrm{hr}$ to $15.67 \mathrm{nGy} / \mathrm{hr}$ (Tables 5a, 6a and Fig. 11). The total absorbed dose delivered by these radionuclides for the soils within Location 1 ranged from $0.38 \mathrm{nGy} / \mathrm{hr}$ to $3.68 \mathrm{nGy} / \mathrm{hr}$ and $1.10 \mathrm{nGy} / \mathrm{hr}$ to $3.43 \mathrm{nGy} / \mathrm{hr}$ within Location 2, having average values of $1.99 \mathrm{nGy} / \mathrm{hr}$ and $2.91 \mathrm{nGy} / \mathrm{hr}$ respectively (Tables 5a and 6a). The estimated absorbed dose values for $500 \mathrm{~m}$ away from the quarry sites are shown in Tables $5 \mathrm{~b}$ and $6 \mathrm{~b}$. The mean total absorbed doses obtained at $500 \mathrm{~m}$ away are $1.74 \mathrm{nGy} / \mathrm{hr}$ and $8.38 \mathrm{nGy} / \mathrm{hr}$ respectively for the two locations. All these values are less than the recommended world average value of $55 \mathrm{nGy} / \mathrm{hr}$ (Fig. 11). The differences arising from these values may be due to the geological settings of the area due to variation from one place to another and from one locality to another even within the same geographical area. The calculated values of annual effective dose ranged between 0.47 to $4.51 \mu \mathrm{Sv} / \mathrm{yr}$ with mean value of $2.44 \mu \mathrm{Sv} / \mathrm{yr}$ within Location 1 and 1.35 to $4.21 \mu \mathrm{Sv} / \mathrm{yr}$ with mean $3.57 \mu \mathrm{Sv} / \mathrm{yr}$ within Location 2 (Tables 5a and 6a). The mean values of effective doses obtained for $500 \mathrm{~m}$ away from the sites are presented in Tables $5 \mathrm{~b}$ and $6 \mathrm{~b}$. It was found that the effective doses obtained at $500 \mathrm{~m}$ away $(10.28 \mu \mathrm{Sv} / \mathrm{yr})$ from Location 2 is higher than that obtained at Location 1 $(2.13 \mu \mathrm{Sv} / \mathrm{yr})$. The mean effective doses are far below the worldwide recommended limit for normal background effective dose of $70 \mu \mathrm{Sv} / \mathrm{yr}$ (Fig. 12). The mean values of annual gonadal equivalent dose (AGED) obtained within the sites are $15.00 \mathrm{mSv} / \mathrm{yr}$ and $21.89 \mathrm{mSv} / \mathrm{yr}$, while, AGED calculated for $500 \mathrm{~m}$ away from each site are 13.11 $\mathrm{mSv} / \mathrm{yr}$ and $63.08 \mathrm{mSv} / \mathrm{yr}$ respectively as shown in Fig. 13. These values are far below the safe limit of $300 \mathrm{mSv} / \mathrm{yr}$ (Fig. 13). This implies that interaction with the soils in the study areas poses no threat to the bone marrow and the bone surface cells of the workers and the populace around the study areas.

The range mean excess lifetime cancer risk (ELCR) calculated for the study areas is 0.009 to 0.067 (Fig. 14). These values are below the world standard of $0.29 \times 10^{-3}$ (Taskin et al., 2009) meaning that the probability of the workers and the people living around the quarry sites developing extra cancer due to exposure to natural radioactivity is insignificant right now, however, continuous accumulation may pose radiological health risks to the people living in the areas in future. Also, the calculated values of the external hazard index, internal hazard index and representative gamma index for soils of the areas are less than the world permissible value of unity (Fig. 14). This indicates that interaction with the soils in the study areas will not result to any respiratory tract disease such as asthma and other external diseases like skin cancer, erythema and cataracts (Avwiri et al., 2013) to the workers involving in quarry activities and users of such soils. Generally, the relatively low gamma dose rates measured from the coarse aggregate rocks and subsurface soils of the two quarry sites show that quarry activities in the areas have not enhanced the background radiation level of the areas. This suggests that the rock aggregates and soils from these quarry sites can be used as building materials for housing construction without posing a health threat to the general public.

Table 3a: Specific activity of ${ }^{40} \mathrm{~K},{ }^{238} \mathrm{U}$ and ${ }^{232} \mathrm{Th}$ and their radium equivalent in soil samples within quarry 1

\begin{tabular}{lllll}
\hline Sample Code & $\mathrm{K}(\mathrm{Bq} / \mathrm{kg})$ & $\mathrm{U}(\mathrm{Bq} / \mathrm{kg})$ & $\mathrm{Th}(\mathrm{Bq} / \mathrm{kg})$ & $\mathrm{Raeq}(\mathrm{Bq} / \mathrm{kg})$ \\
\hline EMC 1 & $43.75 \pm 0.0313$ & $0.022 \pm 0.0012$ & $0.0106 \pm 0.0004$ & 3.4057 \\
EMC 2 & $8.88 \pm 0.0313$ & $0.011 \pm 0.0012$ & $0.0011 \pm 0.0002$ & 0.6961 \\
EMC 3 & $22.37 \pm 0.0313$ & $0.020 \pm 0.0012$ & $0.0015 \pm 0.0003$ & 1.7441 \\
EMC 4 & $48.02 \pm 0.0313$ & $0.044 \pm 0.0012$ & $0.0004 \pm 0.0002$ & 3.7418 \\
EMC 5 & $33.84 \pm 0.0313$ & $0.018 \pm 0.0012$ & $0.0009 \pm 0.0002$ & 2.6244 \\
EMC 6 & $69.47 \pm 0.0313$ & $0.051 \pm 0.0012$ & $0.0011 \pm 0.0003$ & 5.4015 \\
EMC 7 & $65.59 \pm 0.0313$ & $0.022 \pm 0.0012$ & $0.0018 \pm 0.0003$ & 5.0750 \\
EMC 8 & $87.67 \pm 0.0313$ & $0.040 \pm 0.0012$ & $0.0039 \pm 0.0004$ & 6.7965 \\
Mean & $47.45 \pm 0.0313$ & $0.028 \pm 0.0012$ & $0.0027 \pm 0.0003$ & 3.6856 \\
\hline
\end{tabular}

Table 3b: Specific activity of ${ }^{40} \mathrm{~K},{ }^{238} \mathrm{U}$ and ${ }^{232} \mathrm{Th}$ and their radium equivalent in soil samples $500 \mathrm{~m}$ away from the quarry 1 locality

\begin{tabular}{llllll}
\hline Distance $(\mathrm{m})$ & Sample Code & $\mathrm{K}(\mathrm{Bq} / \mathrm{kg})$ & $\mathrm{U}(\mathrm{Bq} / \mathrm{kg})$ & $\mathrm{Th}(\mathrm{Bq} / \mathrm{kg})$ & $\mathrm{Ra}$ eq $(\mathrm{Bq} / \mathrm{kg})$ \\
\hline $\begin{array}{l}500 \mathrm{~m} \text { away } \\
\text { (East) }\end{array}$ & EMC 9 & $45.43 \pm 0.0313$ & $0.019 \pm 0.0012$ & $0 \pm 0$ & 3.5175 \\
$\begin{array}{l}500 \mathrm{~m} \text { away } \\
\text { (West) }\end{array}$ & EMC 10 & $37.65 \pm 0.0313$ & $0.022 \pm 0.0012$ & $0.0015 \pm 1.4941$ & 2.9231 \\
& Mean & $41.54 \pm 0.0313$ & $0.020 \pm 0.0012$ & $0.0008 \pm 0.7470$ & 3.2203 \\
\hline
\end{tabular}


International Journal of Engineering and Geosciences (IJEG), Vol; 3; , Issue; 1, pp. 020-035, February, 2018,

Table 4a: Specific activity of ${ }^{40} \mathrm{~K},{ }^{238} \mathrm{U}$ and ${ }^{232} \mathrm{Th}$ and their radium equivalent in soil samples within quarry of Location 2

\begin{tabular}{lllll}
\hline $\begin{array}{l}\text { Sample } \\
\text { Code }\end{array}$ & $\mathrm{K}(\mathrm{Bq} / \mathrm{kg})$ & $\mathrm{U}(\mathrm{Bq} / \mathrm{kg})$ & $\mathrm{Th}(\mathrm{Bq} / \mathrm{kg})$ & Raeq $(\mathrm{Bq} / \mathrm{kg})$ \\
\hline BMC 1 & $77.39 \pm 0.0313$ & $0.002 \pm 0.0012$ & $0.002 \pm 0.0003$ & 5.9639 \\
BMC 2 & $25.70 \pm 0.0313$ & $0.039 \pm 0.0012$ & $0.009 \pm 0.0004$ & 2.0304 \\
BMC 3 & $81.92 \pm 0.0313$ & $0.036 \pm 0.0012$ & $0.003 \pm 0.0004$ & 6.3485 \\
BMC 4 & $71.45 \pm 0.0313$ & $0.040 \pm 0.0012$ & $0.002 \pm 0.0004$ & 5.5447 \\
BMC 5 & $78.54 \pm 0.0313$ & $0.018 \pm 0.0012$ & $0.001 \pm 0.0003$ & 6.0676 \\
BMC 6 & $70.02 \pm 0.0313$ & $0.024 \pm 0.0012$ & $0.001 \pm 0.0003$ & 5.4170 \\
BMC 7 & $80.68 \pm 0.0313$ & $0.033 \pm 0.0012$ & $0.003 \pm 0.0004$ & 6.2491 \\
BMC 8 & $69.68 \pm 0.0313$ & $0.018 \pm 0.0012$ & $0.008 \pm 0.0004$ & 5.3954 \\
Mean & $69.42 \pm 0.0313$ & $0.026 \pm 0.0012$ & $0.004 \pm 0.0004$ & 5.3771 \\
\hline
\end{tabular}

Table 4b: Specific activity of ${ }^{40} \mathrm{~K},{ }^{238} \mathrm{U}$ and ${ }^{232} \mathrm{Th}$ and their radium equivalent in soil samples $500 \mathrm{~m}$ away from the quarry 2 locality

\begin{tabular}{llllll}
\hline Distance $(\mathrm{m})$ & Sample Code & $\mathrm{K}(\mathrm{Bq} / \mathrm{kg})$ & $\mathrm{U}(\mathrm{Bq} / \mathrm{kg})$ & $\mathrm{Th}(\mathrm{Bq} / \mathrm{kg})$ & $\begin{array}{l}\text { Raeq } \\
(\mathrm{Bq} / \mathrm{kg})\end{array}$ \\
\hline $\begin{array}{lllll}\text { 500 m away (East) } \\
\text { 500 m away }\end{array}$ & BMC 9 & $25.70 \pm 0.0313$ & $0.039 \pm 0.0012$ & $0.009 \pm 0.0004$ & 2.0304 \\
(West) & BMC 10 & $374.93 \pm 0.0313$ & $0.066 \pm 0.0012$ & $0.001 \pm 0.0004$ & 28.9374 \\
& & & & & \\
& Mean & $200.32 \pm 0.0313$ & $0.052 \pm 0.0012$ & $0.005 \pm 0.0004$ & 15.4839 \\
\hline
\end{tabular}

Table 5a: Radiation Hazard parameters for soil samples within Location 1

\begin{tabular}{llllllll}
\hline $\begin{array}{l}\text { Sample } \\
\text { Code }\end{array}$ & $\begin{array}{l}\mathrm{D} \\
(\mathrm{nGy} / \mathrm{hr})\end{array}$ & $\begin{array}{l}\text { AEDE } \\
(\mu \mathrm{Sv} / \mathrm{yr})\end{array}$ & $\begin{array}{l}\text { AGED } \\
(\mathrm{mSv} / \mathrm{yr})\end{array}$ & $\begin{array}{l}\text { ELCR } \\
\left(\times 10^{-}\right.\end{array}$ & $\mathrm{H}_{\mathrm{ex}}$ & $\mathrm{H}_{\mathrm{in}}$ & $\mathrm{I}_{\gamma}$ \\
\hline EMC 1 & 1.84 & 2.26 & 13.85 & 0.008 & 0.009 & 0.009 & 0.029 \\
EMC 2 & 0.38 & 0.47 & 2.83 & 0.002 & 0.002 & 0.002 & 0.006 \\
EMC 3 & 0.94 & 1.15 & 7.09 & 0.004 & 0.005 & 0.005 & 0.015 \\
EMC 4 & 2.02 & 2.48 & 15.22 & 0.009 & 0.010 & 0.010 & 0.032 \\
EMC 5 & 1.42 & 1.74 & 10.69 & 0.006 & 0.007 & 0.007 & 0.023 \\
EMC 6 & 2.92 & 3.58 & 21.98 & 0.013 & 0.015 & 0.015 & 0.047 \\
EMC 7 & 2.75 & 3.37 & 20.67 & 0.012 & 0.014 & 0.014 & 0.044 \\
EMC 8 & 3.68 & 4.51 & 27.67 & 0.016 & 0.018 & 0.018 & 0.059 \\
Mean & 1.99 & 2.44 & 15.00 & 0.009 & 0.010 & 0.010 & 0.032 \\
\hline
\end{tabular}

Table 5b: Radiation Hazard parameters for soil samples 500 m away from Location 1

\begin{tabular}{lllllllll}
\hline Distance $(\mathrm{m})$ & $\begin{array}{l}\text { Sample } \\
\text { Code }\end{array}$ & $\begin{array}{l}\mathrm{D} \\
(\mathrm{nGy} / \mathrm{hr})\end{array}$ & $\begin{array}{l}\text { AEDE } \\
(\mu \mathrm{Sv} / \mathrm{yr})\end{array}$ & $\begin{array}{l}\text { AGED } \\
(\mathrm{mSv} / \mathrm{yr})\end{array}$ & $\begin{array}{l}\text { ELCR } \\
\left(\times 10^{-}\right. \\
3)\end{array}$ & $\mathrm{H}_{\mathrm{ex}}$ & $\mathrm{H}_{\text {in }}$ & $\mathrm{I}_{\gamma}$ \\
\hline 500 m away (East) & EMC 9 & 1.90 & 2.33 & 14.32 & 0.009 & 0.009 & 0.009 & 0.054 \\
$500 \mathrm{~m}$ away (West) & EMC 10 & 1.58 & 1.94 & 11.90 & 0.008 & 0.008 & 0.008 & 0.045 \\
& Mean & 1.74 & 2.13 & 13.11 & 0.009 & 0.009 & 0.009 & 0.049 \\
\hline
\end{tabular}


International Journal of Engineering and Geosciences (IJEG), Vol; 3; , Issue; 1, pp. 020-035, February, 2018,

Table 6a: Radiation Hazard parameters for soil samples within Location 2

\begin{tabular}{llllllll}
\hline $\begin{array}{l}\text { Sample } \\
\text { Code }\end{array}$ & $\mathrm{D}(\mathrm{nGy} / \mathrm{hr})$ & $\begin{array}{l}\text { AEDE } \\
(\mu \mathrm{Sv} / \mathrm{yr})\end{array}$ & $\begin{array}{l}\text { AGED } \\
(\mathrm{mSv} / \mathrm{yr})\end{array}$ & $\begin{array}{l}\text { ELCR } \\
\left(\times 10^{-3}\right)\end{array}$ & $\mathrm{H}_{\mathrm{ex}}$ & $\mathrm{H}_{\text {in }}$ & $\mathrm{I}_{\gamma}$ \\
\hline BMC 1 & 3.23 & 3.96 & 24.32 & 0.014 & 0.016 & 0.016 & 0.091 \\
BMC 2 & 1.10 & 1.35 & 8.23 & 0.005 & 0.005 & 0.006 & 0.031 \\
BMC 3 & 3.43 & 4.21 & 25.85 & 0.015 & 0.017 & 0.017 & 0.097 \\
BMC 4 & 3.00 & 3.68 & 22.57 & 0.013 & 0.015 & 0.015 & 0.085 \\
BMC 5 & 3.28 & 4.02 & 24.72 & 0.014 & 0.016 & 0.016 & 0.093 \\
BMC 6 & 2.93 & 3.59 & 22.06 & 0.013 & 0.015 & 0.015 & 0.083 \\
BMC 7 & 3.38 & 4.15 & 25.45 & 0.015 & 0.017 & 0.017 & 0.095 \\
BMC 8 & 2.92 & 3.58 & 21.97 & 0.013 & 0.015 & 0.015 & 0.083 \\
Mean & 2.91 & 3.57 & 21.89 & 0.012 & 0.015 & 0.015 & 0.082 \\
\hline
\end{tabular}

Table 6b: Radiation Hazard parameters for soil samples 500 m away from Location 2

\begin{tabular}{lllllllll}
\hline Distance $(\mathrm{m})$ & $\begin{array}{l}\text { Sample } \\
\text { Code }\end{array}$ & $\begin{array}{l}\mathrm{D} \\
(\mathrm{nGy} / \mathrm{hr})\end{array}$ & $\begin{array}{l}\text { AEDE } \\
(\mu \mathrm{Sv} / \mathrm{yr})\end{array}$ & $\begin{array}{l}\text { AGED } \\
(\mathrm{mSv} / \mathrm{yr})\end{array}$ & $\begin{array}{l}\text { ELCR } \\
\left(\times 10^{-3}\right)\end{array}$ & $\mathrm{H}_{\text {ex }}$ & $\mathrm{H}_{\text {in }}$ & $\mathrm{I}_{\gamma}$ \\
\hline $500 \mathrm{~m}$ away (East) & BMC 9 & 1.10 & 1.35 & 8.23 & 0.005 & 0.016 & 0.016 & 0.031 \\
$500 \mathrm{~m}$ away (West) & BMC 10 & 15.67 & 19.22 & 117.94 & 0.067 & 0.005 & 0.006 & 0.443 \\
& Mean & 8.38 & 10.28 & 63.08 & 0.036 & 0.011 & 0.011 & 0.237 \\
\hline
\end{tabular}




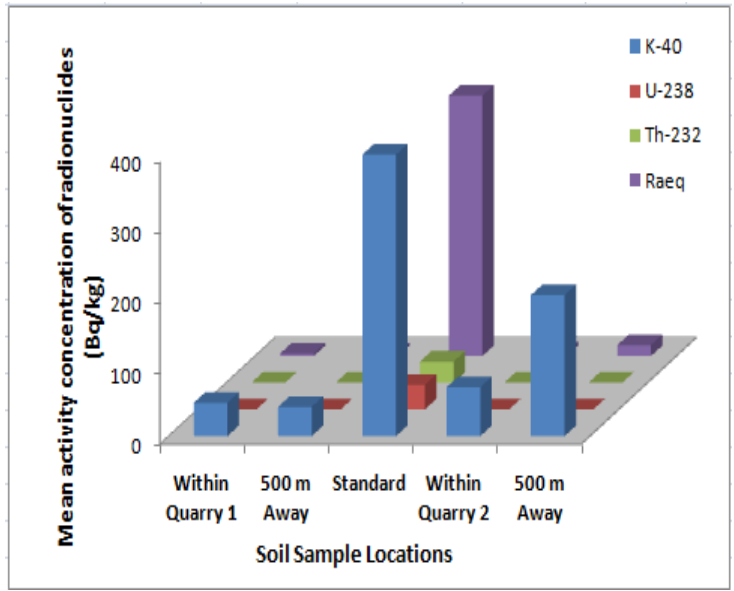

Figure 10. Mean activity concentrations of radionuclides in soils of the study area compared with the UNSCEAR, 2000.

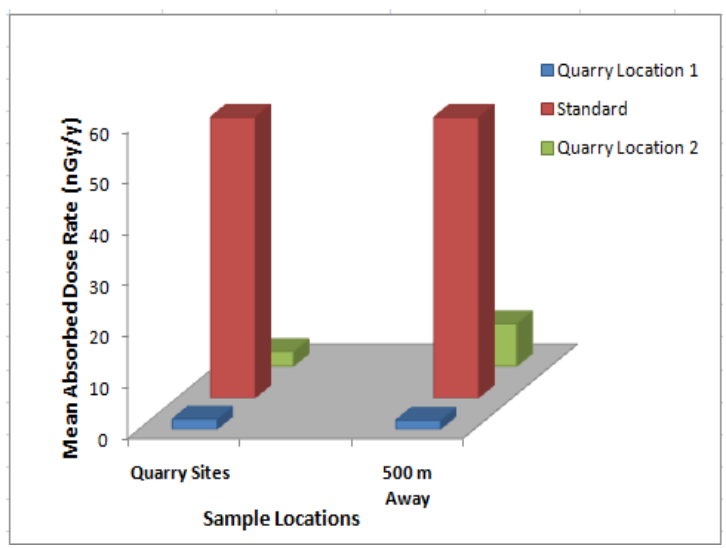

Figure 11. A comparison of the absorbed dose rate $(\mathrm{nGy} / \mathrm{h})$ in soil of the study areas with the UNSCEAR, 2000.

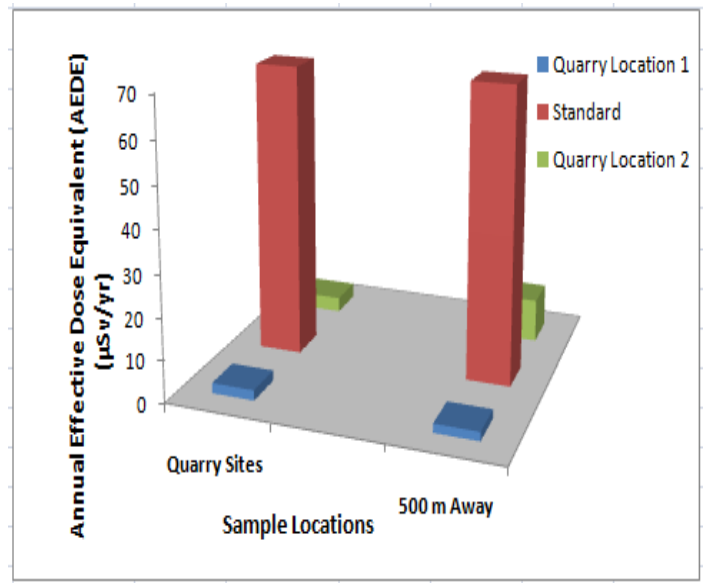

Figure 12. A comparison of the Annual Effective Dose Equivalent (outdoor) (AEDE) in soils of the study areas with the UNSCEAR, 2000.

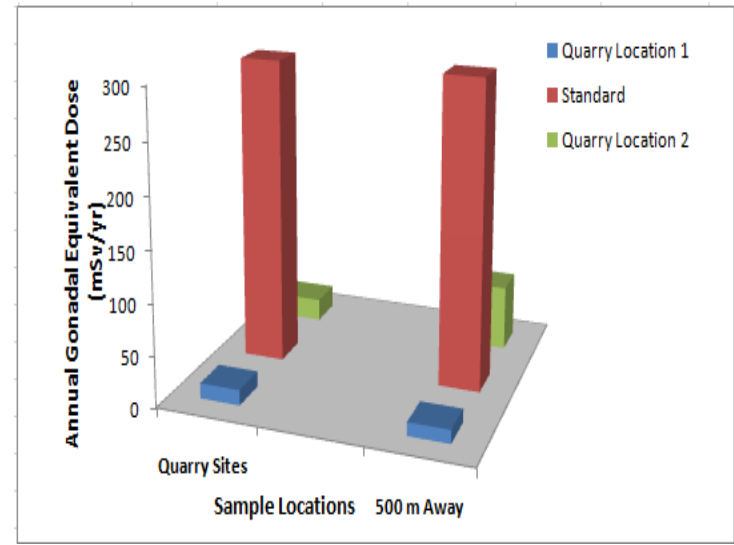

Figure 13. Annual Gonadal Equivalent Dose (AGED) in soils of the study areas compared with the UNSCEAR, 2000.

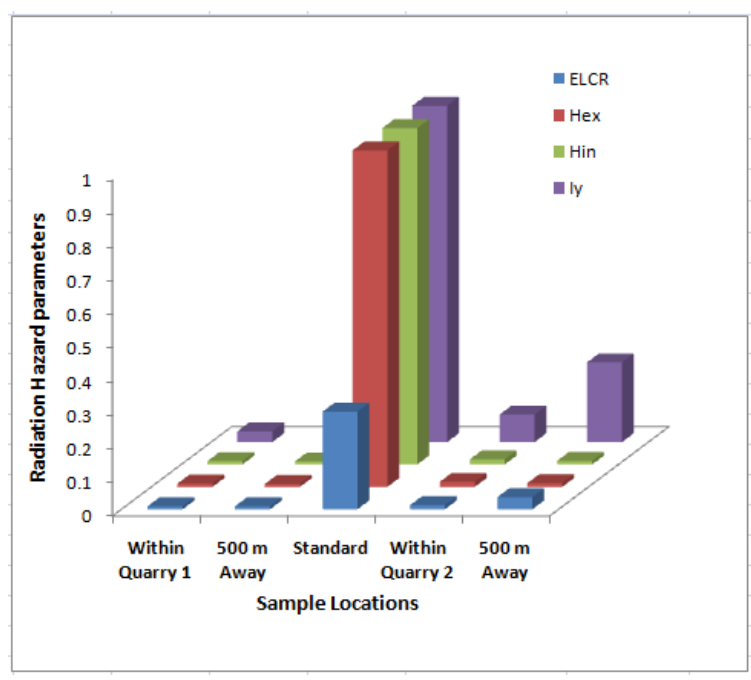

Figure 14. Excess Lifetime Cancer Risk, External hazard index, Internal hazard index and Gamma Representative Index in soils of the study areascompared with the UNSCEAR, 2000

\section{CONCLUSION}

The fact that quarry activities have the potential to increase the radiation dose received by individuals, radiometric survey has proved to be a useful tool in detecting the radiogenic emissions of most common radioactive elements in the study areas. The gamma count is a function of the concentration of radioactive elements in the rock. The higher values of radiation in the recently quarried coarse rock aggregates compared with the previously quarried coarse aggregate are an indication that radionuclides are resident in the parent rock materials. Also, relatively higher values of the radiations in the coarse aggregates of porphyritic granite gneiss compared with the coarse aggregates of fine to medium grained banded gneiss in this study implies that fine to medium grained rocks absorb and reflect radiation more easily than rocks of predominantly coarse grains. This shows that radionuclide level in rocks is influenced by grain size distribution. 
The radioactivity concentrations of ${ }^{238} \mathrm{U},{ }^{232} \mathrm{Th}$ and ${ }^{40} \mathrm{~K}$ in rock aggregates and soil samples of the two quarry sites showed that there are low level activities in the areas as they were far below their respective world standard values. The radionuclides are randomly distributed in the rock aggregates and soil with ${ }^{40} \mathrm{~K}$ being the dominant radionuclide in the soils of the areas. The average dose rates and the annual effective dose equivalent calculated are very low compared to the world standard values for radiological hazard in humans. The other calculated radiation parameters (indices) including the excess lifetime cancer risk, radium equivalent, annual gonadal equivalent dose, representative gamma index, external and internal hazard indices for rock aggregates and soils of the areas are less than the world permissible value of unity. This indicates that interaction with the rock aggregates and soils do not expose the workers and the people within and around the areas to health problem.

Generally, the relatively low gamma dose rates measured from the coarse rocks aggregate and subsurface soils of the two quarry sites show that quarry activities in the areas have not enhanced the background radiation level of the areas. This suggests that the rock aggregates and soils from these quarries can be used as building materials for housing and construction of roads without posing a health threat to the general public.

It is necessary to determine the radiation levels in and around quarries and different rock aggregates and soils before supply to the end users in construction works. This will definitely reduce the exposure of workers, users of such building materials and the populace to radionuclide radiations. This suggests that quarry activities need to be continuously monitored and workers occupancy in the quarry sites need to be controlled as exposure to the dose level over a long period can constitute serious health hazard especially to the quarry activities operators on the site and also the intake from inhaled and ingested radioactivity could present risks to workers and populace around the area. Based on this study, it is recommended that quarries must continuously be investigated of radiation level to ensure safety of lives of people and secure their health.

\section{REFERENCES}

Avwiri, G.O., Osimobi, J.O. and Agbalagba, E.O., 2012. Evaluation of radiation hazard indices and excess lifetime cancer risk due to natural radioactivity in soil profile of Udi and Ezeagu Local Government Areas of Enugu State, Nigeria. Journal of Environmental and Earth Sciences, 1(1), 1-10.

Avwiri, G.O., Egieya, J.M. and Ononugbo, C.P., 2013. Radiometric assay of hazard indices and excess lifetime cancer risk due to natural radioactivity in soil profile in Ogba/Egbama/Ndoni Local Government Area of Rivers State, Nigeria. Academic Research International, 4(5), 54-65.

Beretka, J. and Mathew, P.J., 1985. Natural radioactivity of Australia building materials industrial wastes and byproducts. Health Physics, 48, 87-95.
Brimhal, W.H. and Adams, J.A.S., 1982. Concentration changes of thorium, uranium and metals in hydrothermally altered Conway Granite, New Hamsphire. Geochim, Cosmochim Acta, 33, 130-131.

David, O., 1998. Mining and quarrying occupational health and safety committee. Quarrysafe hazardous substances in quarries.

Environmental Measurement Laboratory (EML) manual, 1983. Volchok, Herbert, L., dePlanque, Gail (Eds.), twenty-sixth ed. New York, US Department of Energy, Environmental Measurement Laboratory.

Gunn, P., Minty, B. and Milligan, P., 1997b. The airborne gamma-ray spectrometric response over Arid Australian Terranes. In A. Gubins (Ed.), Proceedings of Exploration 97: Fourth Decennial International Conference on Mineral Exploration, Australia. 733-740.

IAEA, 1991. Airborne gamma ray spectrometer surveying, International Atomic Energy Agency, Technical Report Series, No. 323, 97.

IAEA, 2003. International Atomic Energy Agency (IAEA) guidelines for radioelement mapping using gamma ray spectrometry data, Vienna.

James, L.W., 2013. Health hazards of mining and quarry ing, safework_bookshelf. http: // www. Ilo.org/safework _bookshelf/English?content\&nd=857170934.

Milsom, J., 2003. Field Geophysics: The geological field guide series, John Milsom University College, London. Published by John Wiley and Sons Ltd. Third edition. 5170

Montaj $^{\mathrm{TM}}$ Tutorial, 2004. Two-Dimensional frequency domain processing of potential field data.

Rahaman, M.A., 1989. Review of the basement geology of southwestern Nigeria. In: Kogbe, C.A., (ed) Geology of Nigeria, Rock View (Nig.) Limited, Jos, Nigeria. 3956.

Ramasamy, V., Suresh, G., Meenakshisundaram, V. and Gajendran, V., 2009. Evaluation of natural radionuclide content in river sediments and excess lifetime cancer risk due to gamma radioactivity. Research Journal of Environmental and Earth Sciences, 1(1), 6-10.

Taskin, H., Karavus, M., Topuzoglu, A., Hindiroglu, S. and Karahan, G., 2009. Radionuclide concentrations in soil and lifetime cancer risk due to the gamma radioactivity in Kirklareli, Turkey. Journal of Environmental Radioactivity, 100, 49-53.

Tim Driscoll, Steenland, K., Nelson, D.I. and James, L., 2004. Environmental Burden of Disease Series, No. 7; World Health Organization Protection of the Human En vironment, Geneva.

Tufail, M., Akhar, N., Jaried, S.A. and Hamid, T., 2007. Natural radiation hazard in building bricks fabrication from soils of two districts of Pakistan. Radiological Protection, 27, 481-492. 
UNSCEAR, 2000. United Nations Scientific Committee on the Effects of Atomic Radiation. Sources, effects and risks of ionizing radiation. Report to the general assembly, annexes B: Exposure from natural radiation sources. New York. 678-679.

Veiga, R.G., Sanches, N., Anjos, R.M., Macario, K., Bastos, J., Iguatemy, M., Aguitar, J.G., Santos, M.A., Mosquera, B., Carvaiho, C., Baptista, M. and Umisedo, N.K., 2006. Measurement of natural radioactivity in Brazilian beach sands. Radiation Measurements, 41, 189196.

Wilford, J., Bierwirth, P. and Craig, M., 1997. Application of gamma-ray spectrometry in soil or regolith mapping and applied geomorphology. Journal of Australian Geology and Geophysics, 17(2), 201-216. 